\title{
A REVIEW ON CURRENT ADVANCES IN THE ENERGY AND ENVIRONMENTAL PERFORMANCE OF BUILDINGS TOWARDS A MORE SUSTAINABLE BUILT ENVIRONMENT
}

N. Soares ${ }^{a, b}$, J. Bastos ${ }^{a}$, L. Dias Pereira ${ }^{a}, A$. Soares $^{c, d}$, A.R. Amaral ${ }^{a}$, E. Asadi ${ }^{a}$, E. Rodrigues ${ }^{a}$, F.B. Lamas ${ }^{a}$, H. Monteiro ${ }^{a}$, M.A.R. Lopes ${ }^{\mathrm{e}, \mathrm{f}}$, A.R. Gaspar ${ }^{\mathrm{a}}$

\footnotetext{
${ }^{a}$ ADAI, LAETA, Department of Mechanical Engineering, University of Coimbra, Pólo II, Rua Luís Reis Santos, 3030-788 Coimbra, Portugal

${ }^{\mathrm{b}}$ ISISE, Department of Civil Engineering, University of Coimbra, Pólo II, Rua Luís Reis Santos, 3030788 Coimbra, Portugal

${ }^{c}$ Vlaamse Instelling voor Technologisch Onderzoek - VITO, Boeretang 200, $2400 \mathrm{Mol}$, Belgium

dEnergyVille, Thor Park 8310, 3600 Genk, Belgium

e INESC Coimbra, Rua Antero de Quental 199, 3000-033 Coimbra, Portugal

${ }^{\dagger}$ Department of Environment, ESAC - Polytechnic Institute of Coimbra, 3045-601 Coimbra, Portugal
}

\section{The final publication is available at Elsevier via https://doi.org/10.1016/j.rser.2017.04.027}




\title{
A REVIEW ON CURRENT ADVANCES IN THE ENERGY AND ENVIRONMENTAL PERFORMANCE OF BUILDINGS TOWARDS A MORE SUSTAINABLE BUILT ENVIRONMENT
}

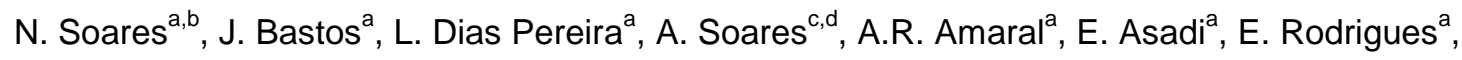 \\ F.B. Lamas ${ }^{a}$, H. Monteiro ${ }^{a}$, M.A.R. Lopes ${ }^{\mathrm{e}, \mathrm{f}}$, A.R. Gaspar ${ }^{\mathrm{a}}$
}

\begin{abstract}
${ }^{a}$ ADAI, LAETA, Department of Mechanical Engineering, University of Coimbra, Pólo II, Rua Luís Reis Santos, 3030-788 Coimbra, Portugal

b ISISE, Department of Civil Engineering, University of Coimbra, Pólo II, Rua Luís Reis Santos, 3030-

788 Coimbra, Portugal

${ }^{\circ}$ Vlaamse Instelling voor Technologisch Onderzoek - VITO, Boeretang 200, $2400 \mathrm{Mol}$, Belgium

${ }^{\mathrm{d}}$ EnergyVille, Thor Park 8310, 3600 Genk, Belgium

e INESC Coimbra, Rua Antero de Quental 199, 3000-033 Coimbra, Portugal

${ }^{\dagger}$ Department of Environment, ESAC - Polytechnic Institute of Coimbra, 3045-601 Coimbra, Portugal
\end{abstract}

\begin{abstract}
Nowadays, debates addressing climate change, fossil fuels depletion and energy security highlight the need for a more sustainable built environment in order to reduce energy consumption and emission trends in the buildings sector. Meeting these targets is a challenge that calls for innovative research to improve the use of renewable energy sources, new technologies, and holistic tools and methodologies. Such research should integrate the dynamics and main drivers of energy supply and demand in buildings to support new policies, plans and actions towards lowering the built environment burdens. This paper brings together ten research topics concerning the energy and environmental performance of buildings, which can support a shift towards a more sustainable built environment. Background information and state of the art literature on the covered research topics is briefly summarized, gaps are identified and guidelines for future research are provided. The selected topics cover different stages along the lifetime of buildings (from design and operation, to retrofitting and endof-life), different scale approaches (from building elements/components, to the building, district and urban scales), and different methods to assess the energy and environmental performance of buildings (life-cycle assessment, generative design methods and retrofitting tools). Other topics are discussed such as: nearly zero-energy buildings, the control of domestic energy resources in smart grid scenarios, the need to include end-users' behaviors in the dynamics of energy demand, the advantages of improving thermal storage by using phase change materials, the importance of reducing heating and cooling energy demand (maintaining indoor thermal comfort), and the optimization of heating and cooling fluids, and their system control.
\end{abstract}

\section{Keywords}

Buildings, Environmental performance, Energy efficiency, Thermal performance, Design and retrofitting, End-users behaviors. 


\section{Contents:}

Introduction

1. How can LCA contribute to an improved environmental performance of buildings?

2. Why should the urban scale be addressed in the environmental assessment of buildings?

3. Why should NZEB take into account the urban context in the energy performance assessment?

4. How should domestic energy resources be controlled in a smart grid scenario?

5. How much energy saving potential in buildings can be achieved by end-use energy behaviors?

6. Why should indoor environmental quality be integrated in buildings' energy performance assessment?

7. How can generative design methods contribute to the improvement of buildings' performance?

8. What are the different methodologies for the assessment of building retrofit actions?

9. How can thermal energy storage systems with PCMs improve buildings' energy performance?

10. How can HVAC fluids and transport fluid movers improve buildings' overall energy efficiency?

Conclusions

\section{Abbreviations:}

$\begin{array}{ll}\text { EE } & \text { Energy efficiency } \\ \text { HVAC } & \text { Heating, ventilation, and air conditioning } \\ \text { IAQ } & \text { Indoor air quality } \\ \text { IEQ } & \text { Indoor environmental quality } \\ \text { LCA } & \text { Life cycle assessment } \\ \text { NZEB } & \text { Nearly zero-energy building } \\ \text { PCM } & \text { Phase change material } \\ \text { TC } & \text { Thermal comfort } \\ \text { TES } & \text { Thermal energy storage }\end{array}$

\section{Introduction}

The built environment has been in the focus of energy and environmental debates and policies, and the need to reduce greenhouse gas emissions to meet targets by 2020 [1] and improve energy security has motivated a large body of literature on energy efficiency and environmental impacts associated with buildings. The improvement of the energy and environmental performance of buildings calls for innovative research, new policies and standard regulation, new materials and technologies, the integration of renewable energy sources and increased outreach and people awareness (designers, practitioners and end-users). The operation of buildings has been often focused in the literature: in conventional buildings, this stage dominates energy demand and environmental impacts. Buildings have a long service life, during which end-users' expectations should be met, including 
thermal comfort (TC) and indoor environmental quality (IEQ) requirements. As research and policies succeed in reducing the impacts of buildings' operation, the relative contribution of other life-cycle stages has increased, and integrated and holistic approaches are needed to avoid problem-shifting. Reducing energy and environmental impacts associated with the built environment is a challenging task, which requires a comprehensive understanding of the dynamics and main drivers of energy demand and environmental impacts.

This paper addresses ten topical questions towards the improvement of the energy and environmental performance of buildings, drawing on a focused literature review to provide directions for future research. Figure 1 illustrates the main topics covered in this paper: life-cycle assessment (LCA), urban planning, district scale nearly zero energy buildings (NZEBs), smart grid scenarios, IEQ and $T C$, assessment of building retrofitting actions, generative building design methods, thermal storage with phase change materials (PCMs), HVAC fluids (strategies and control), the importance of improving the use of renewables, the importance of end-users' behaviors and the need to use dynamic approaches. The topics follow two lines of research:

- the use of integrated and holistic approaches to assess and improve the energy and environmental performance of buildings, and

- the development of new solutions, technologies, materials and dynamic methodologies.

Opportunities for improving the energy and environmental performance of buildings are pointed out, and an outlook for future developments is presented. This paper covers a diversity of issues that have been typically addressed individually in the literature, due the complexity and multidisciplinary character of building systems and their energy and environmental performance. The review aims at providing a holistic perspective, bringing together fragmented research and highlighting the potential for multidisciplinary approaches to achieve environmental targets and to improve the sustainability of the built environment. 


\section{RESEARCH GAPS}

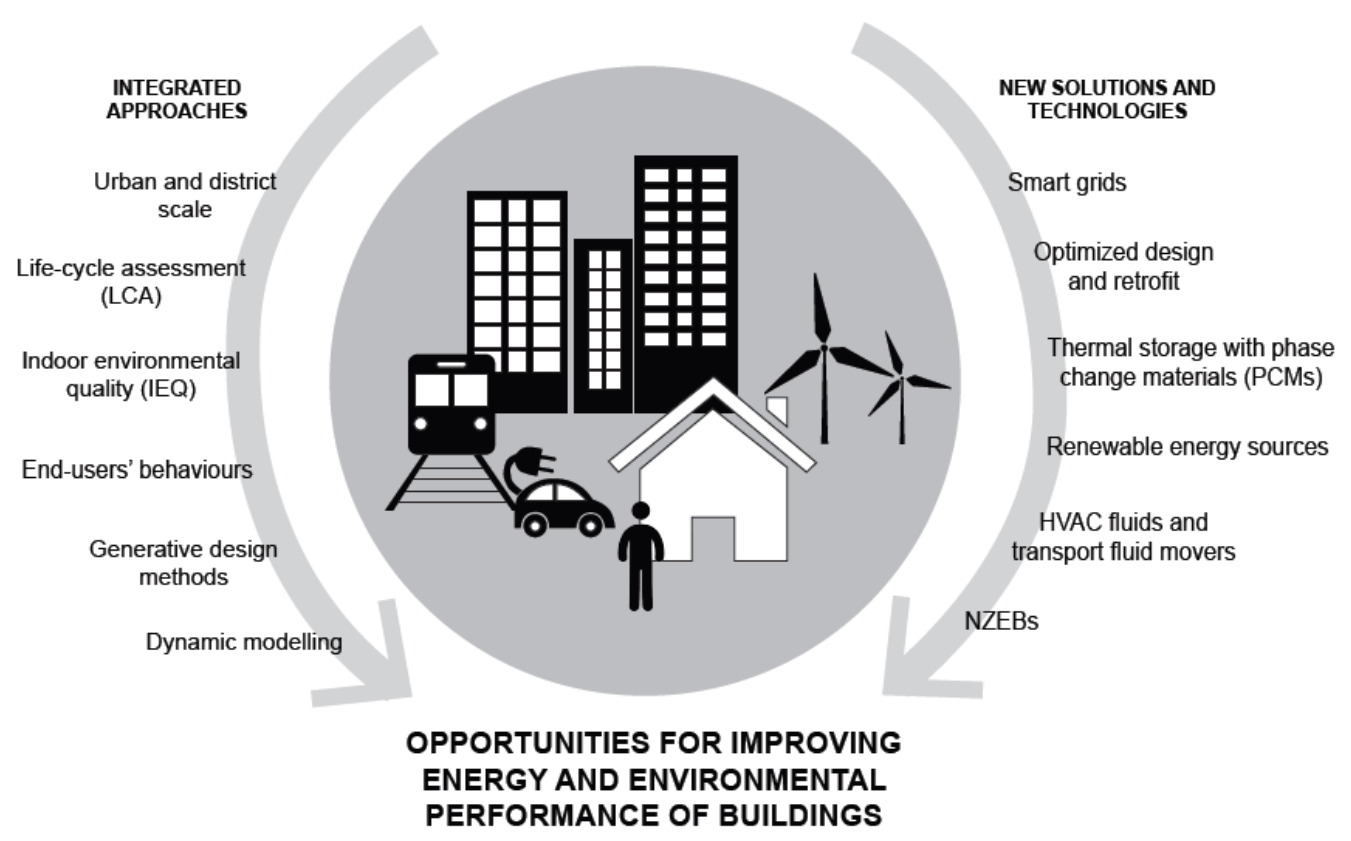

Figure1. Main research topics addressed.

\section{How can LCA contribute to an improved environmental performance of buildings?}

Many efforts have focused on reducing operational energy demand and developing new low-energy buildings [2]. However, decreasing operational energy demand often results in an increase of embodied requirements. LCA is a methodology to calculate potential environmental impacts, associated to material and energy flows, through different life-cycle phases of a product (or process) from "cradle to gate" or "from cradle to grave", and it is usually used in the industrial context to improve the environmental performance of products [3]. The LCA framework is defined by ISO14040 series $[4,5]$ and includes four iterative steps: goal and scope definition, life-cycle inventory, life-cycle impact assessment and interpretation of results. Over the last 15 years, LCA has been used in the construction and building context to address the tradeoffs between different building life-cycle phases and building components and to help identifying the most effective opportunities for reducing impacts.

LCA studies in the built environment context have rapidly increased in number, covering different scales, from assessments or comparisons of alternative construction materials [6-9] (e.g., wood, brick, concrete, insulation materials [10-14]) and building components (exterior walls [15-22]; roofs [23-25]; structures $[6,9,26,27]$ ) to buildings as a whole (offices [27,28]; schools [29]; residential buildings: either conventional or low-energy [30-37] and refurbishments [25,38-43]. Life-cycle impact assessment categories selected vary among studies: some cover only primary energy $[8,34,44,45]$ and greenhouse gas (GHG) emissions [46-48], whereas others include a wider range of environmental categories $[15,33,49,50]$ (e.g., abiotic depletion, acidification, eutrophication, photochemical oxidation, ozone layer depletion, land use change) presenting more comprehensive assessments. Review studies on the topic [51-55] concluded that LCA can provide valuable insights towards selecting 
improved construction options and heating systems. Most research articles are based on specific case studies, and life-cycle modeling assumptions generally vary among studies (building type; shape; construction; climate; comfort levels; boundary conditions) thus the comparison among different available studies is not easy to perform [53,54]. Whereas many studies concluded that use phase dominates the life-cycle burdens of conventional buildings (representing a range of $60-90 \%$ of overall life-cycle in residential buildings $[30,31,53,56])$, other studies pointed out that in low-energy buildings construction phase, (including the embodied impacts) can represent up to $50 \%$ of the overall life-cycle impacts $[53,57,58]$. Neglecting the need for a life-cycle perspective when implementing and assessing potential impacts of new buildings, might result in problem-shifting: to spend more energy upfront than the one being saved by energy efficiency measures [38]; problem shifting is likely to occur in new dwellings focused mainly on optimizing operational energy and costs [59], but also in dwellings with lower operational patterns, due to the user behavior "prebound" effect $[60,61]$, and in mild climate conditions [37].

Since it is generally recognized that LCA can effectively support decision-making toward the selection of improved building options, the CEN TC 350 group [62] has been working on defining new standards to provide common rules for the environmental assessment of buildings [63]. Moreover, as the use of LCA to support buildings developments is a recent topic, several challenges for further work have been identified. Different life-cycle inventory approaches have been explored [44] (process based; input-output; and hybrid). The bottom-up process analysis is the most used at building scale, because it relies in detailed data at product level allowing the comparison between building alternatives, but it is known to suffer from a truncation error, underestimating indirect impacts or excluding processes along the chain due to the need for a system boundary. The top-down inputoutput approach is based on different activity sectors, energy intensity and economic data, but it does not allow to easily disaggregate impacts from products within the same sector. In order to overcome these limitations, hybrid approaches have been developed [44]. The choice for the most adequate lifecycle inventory approach should be based on the goal and scope of the LCA study.

Buildings are complex systems, which incorporate multiple construction materials and processes that can come from different industries and producers. Although extensive international inventory data is available for energy production systems and construction materials (e.g., ecoinvent database $[64,65]$ ), local construction materials assume a significant share in buildings, and the implementation of more accurate assessments could benefit from national databases, with data from local producer [66]. Natural materials, such as wood, seem to have lower impact than other materials $[6,7,9,15,67]$ (e.g., concrete or brick) but their embodied impact depends on the production chain including wood growth, harvesting procedures, and forest regeneration, which vary from place to place and go beyond the building scale. As opposed as standardized/industrialized products, buildings are usually one of a kind product and, therefore, it is not linear to draw general conclusions: buildings have a unique location (being exposed to specific local features and climatic conditions) and they are inhabited by different end-users (different occupation and operational patterns), that highly influence operational energy use. To compare the life-cycle performance of different buildings, ranges of similar assumptions can be used to draw conclusions. For instance, to compare buildings under similar 
weather conditions (for a climatic region), with alternative occupational/operational patterns framing possible/typical user variation through scenarios (prebound effect [60], and rebound effect [61]), and using regional energy mixes $[37,50,68]$. Thus, life-cycle studies of buildings should cover regional contexts instead of claiming broad generalizations, because the specifics of regional aspects can shift the conclusions of a study $[37,50,68]$.

LCA studies of buildings often use a static approach (assuming the same conditions over the building life span). But as long lasting products, such assumption may incorporate high uncertainty over time. Predicting and modeling future changes is challenging and requires further research efforts, namely for the following reasons:

- the total building service life is uncertain (50-100 years) and the schedule and nature of maintenance activities (corrective, preventive or predictive) can highly influence the life span;

- the service life of active systems is shorter than that of most building components and thus, they will likely be replaced by more efficient systems, which is hardly predictable;

- the electricity production mix changes over time, affecting operational phase impacts [50]; and,

- buildings will eventually be demolished or dismantled, but their end-of-life and future construction waste treatment scenarios are uncertain.

\section{Why should the urban scale be addressed in the environmental assessment of buildings?}

While the environmental assessment of buildings has had significant developments in the last decades, there is an important opportunity in integrating the urban scale in environmental research and policies. Urban design is directly and inherently linked to the environmental performance of an individual building, as it is often determinant for its typology and orientation, for example [69]. However, less straightforward linkages play a crucial role and research is needed to better understand and explore the specific influence of urban form on energy and environmental requirements and emissions [70]. Here, we address the linkages between urban form and environmental impacts associated with buildings, focusing on the following issues: accounting for urban microclimate effects, understanding how land use planning variables affect environmental performance of urban areas and how they affect travel demand. We discuss the need to integrate the urban scale in environmental assessment and policies, and the potential of urban design and planning to contribute for a more sustainable development.

Previous literature has addressed the relationship between buildings' environmental performance and the urban scale. Rickwood et al. [69] provided a comprehensive review on the relationship between urban structure, energy demand and greenhouse gas emissions, covering the linkages between urban design, buildings' performance and travel demand. The authors concluded that two links should be further explored to understand and use urban planning potential for reducing energy demand: the linkage between dwelling type and in-dwelling energy use, and the linkage between urban structure and transport-related energy use. Heinonen and Junnila [71] compared the 
energy consumption requirements of urban and rural households in Finland for apartment buildings, row/terrace houses, and detached houses, separately. The authors explored the differences between urban and rural living, and between housing types, and found that behavioral differences were significant between different housing typologies and that across all typologies rural households had lower energy requirements.

Most debate on the influence of urban form on environmental performance of urban areas has focused on density, in particular dwelling or resident population densities, and its influence in the performance of residential buildings or passenger transportation, separately [69]. In general, low density in urban areas has been associated with increased energy requirements and environmental impacts [69-73], while high-density living (based on apartment buildings) has been often considered to be a more sustainable living model [71]. For buildings, however, occupancy issues are likely to explain a large share of such evidence, in particular the current rapid increase in living space per person [7173]. In addition, although apartment buildings might be expected to generally have a better environmental performance (because they have a lower ratio of external envelope per square meter of living area [71]), different operating requirements associated with common areas and infrastructure, such as lifts, might narrow the difference between these and lower density housing typologies [74]. Regarding transport demand, the lower energy requirements and environmental impacts associated with dense areas have been mainly related to better accessibility, shorter trips and higher efficiency of transit [69]. However, density might increase congestion problems and commuting time, in particular due to the centralization of jobs, and thus smart growth strategies have generally supported the development of higher density clusters linked by public transport networks. Other variables that characterize urban form have been addressed, although less explored, such as accessibility and land use mix $[75,76]$.

At the design stage, considering the urban context is crucial to address urban microclimate effects, as well as public, street space and accessibility, such as day lighting width and building height ratios, which strongly influence the environmental performance of buildings [77,78]. As an example, Niemasz et al. [79] explored daylight and shading of buildings and public space, showing that oversized buildings offsets do not necessarily translate in significant decrease of energy use in dwellings, but they are likely to compromise walkability and lead to higher transportation requirements. For the environmental assessment of new and existing buildings, addressing the urban scale is crucial to account for urban microclimate effects, such as considering urban form variables (e.g., building types and vegetation) to consider urban heat island effects $[77,80]$.

Generally, research has either focused on transport or in-dwelling energy and environmental impacts, but not both [69]. However, the location of a building determines the transportation demand of its inhabitants and, in order to support decision-making at the urban scale and avoid trade-offs, it is important that the two are also addressed together, in integrated approaches [69,81,82]. Few assessments have addressed both transport and buildings energy and environmental performance despite the fact that they are both strongly affected by urban design and planning policies [69]. Bastos et al. [81], which comprised a comparative life-cycle study for dwellings considering building 
construction, building use and user transportation, included a brief review on nine previous life-cycle studies that integrated transportation and buildings $[44,70,72,73,83-87]$.

Two issues that strongly affect research and comparative environmental assessments of buildings and urban areas should be highlighted: self-selection biases and functional units. Although a large body of research has proved strong correlation linkages between urban form and energy use or environmental performance (especially focusing on density), it is important to stress that it does not establish a causal link. The linkages between buildings and transportation environmental performance and urban form are complex and selection bias can hardly be controlled for [69]. As an example, it is difficult to distinguish demographic from urban form effects on buildings' energy use and environmental performance (e.g., denser areas in many cities are likely to have lower income residents) [69]. In addition, the results depend on the unit of analysis, most often being per floor area (square meter) or per capita [71].

In the last decades, significant progress was made in monitoring, assessing and managing energy requirements and environmental performance of buildings [77]; however, research has focused on isolated buildings and aspects, such as operational energy use, and there is an opportunity to expand to the urban scale, to support decision-making and guidelines for regional planning, urban and architectural design, which has great potential to achieve more sustainable growth and development $[77,88]$. The design, location and local urban characteristics affect the environmental performance of a building, and focusing on the individual building, neglecting potential interactions with the urban scale, might shift impacts, have counterintuitive results and overlook improvement opportunities for a more sustainable urban development $[69,77,81,82]$. Future research should thus address the linkages of urban form, buildings and transportation environmental performance with integrated and holistic approaches, to support design and decision-making and managing the building stock.

\section{Why should NZEB take into account the urban context in the energy performance assessment?}

The European growth strategy for the present decade, known as Europe 2020 [89], lead to the Recast of the EPBD (Energy Performance of Buildings Directive) in 2010, which brought the concept of NZEB [2] to the forefront. This has been seen as a promising approach to minimize the energy consumption and $\mathrm{CO}_{2}$ emissions in the building sector and, at the same time, to increase the penetration of renewable sources in energy production. However, and although relevant work can be found in literature on the proposal of definitions and requirements [90-96], there is still missing a comprehensive framework to characterize NZEB, namely in the urban context. Knowing that the buildings' sector accounts for the largest energy consumption [97], and that the world's population tends to concentrate in cities [98], it can be assumed that energy consumption intensity in urban buildings will continue to increase, and further efforts are needed to counteract such tendency.

The recent interest on the district as an intermediate scale has brought a new emphasis to the study of both buildings and cities, whose energy efficiency has been studied distinctly, based on the 
premise that buildings behave as isolated units that encapsulate all the requirements, neglecting the need to have shared resources and, particularly, the influence of urban scale phenomena [99]. On the other hand, urban forms have been studied, for instance, on the design of a city as a whole, and a major attention has been given to the sustainability in urban development [100], with the emergence of several assessment methodologies [101-106]. As a recent approach in the literature, the boundaries of this intermediate scale are not yet well defined; block, district, neighborhood or community are terms that reveal an attempt of understanding how buildings interact with near surroundings and how these affect their energy performance.

The challenging mission of NZEB concept lies in aiming to reach a clear balance between energy consumption and production. For that, the elements that feature the design of these buildings are:

- from the demand side - efficient opaque envelopes and glazing areas, efficient heating and cooling systems, good ventilation methodologies, efficient water heating systems, efficient lighting systems and appliances, etc.;

- from the supply side - technologies based on renewable energy sources and efficient building energy management systems $[107,108]$.

These are very important and unquestionable factors; however, in the urban context, buildings' performance cannot be assessed individually. There are factors intrinsic to neighborhood patterns that may play an important role in buildings performance, such as airflows and heat island effect generated by urban environment [109,110], buildings' shape [111-113], or even occupants' behavior [99,114].

Amongst these factors, the urban morphology, namely through geometry, should be also considered in the energy performance assessment [115] and, in this topic, urban form and density assume an essential role, mainly due to the shading effect that buildings produce on each other, which can make unfeasible some design strategies related to solar availability. In literature, the key solution for the energy efficiency of urban buildings and for achieving an NZEB at a district scale is related to the solar potential of urban areas, and how buildings' shape can affect solar availability, energy demand and energy supply [116-124].

The main advantage of studying the behavior of buildings as a part of a quarter or a district is the possibility of sharing resources and systems, in order to optimize efficiency and cost investments, and this brings a special attention to the heating and cooling systems, as well as the energy production at a district scale. Some studies have shown that district heating and cooling systems are advantageous when compared to individual ones, in terms of environmental impact, investment costs and services demand, depending on the urban density [125-129]. Moreover, they are referred as helping NZEB to have an important role in the construction of smart cities [130]. Therefore, density can help to delimitate this boundary of efficiency, and although several studies recognize this importance [113,131-134], a broad and consensual definition is still missing.

In this sense, it can be concluded that few studies have focused in an approach to the study of NZEB at a neighborhood scale, and have concentrated in specific objectives [135]. Taking into consideration that, for all European Member States, new private buildings must meet NZEB goals from 
2020, it becomes increasingly important to enrich this field of studies, contributing to a consensual definition and congregation of all the referred influencing requirements in NZEB at the district scale, as well as several ways and methodologies to put them into practice. In this way, it will be possible to rule effective urban policies guided by environmental and energy concerns, reflecting Europe 2020 targets.

\section{How should domestic energy resources be controlled in a smart grid scenario?}

As mentioned before, the buildings sector is one of the largest energy consumers representing $32 \%$ of the global energy use [136], and special attention should be paid to this sector. Sustainable energy consumption comprises making a more conscientious use of electricity, including producing electricity locally based on renewables, and using it with the ultimate goal of reducing overall consumption.

In the context of smart grids, power systems will be endowed with bidirectional communication, computing, control and information technologies enabling the end-user to react in a near real time environment to dynamic tariffs. Several studies have already shown that feedback on household electricity consumption can by itself act as stimuli for a more efficient behavior and originate savings $[137,138]$. Therefore, with the right incentives and technology, end-users may adopt a more active role, namely through the adjustment of energy demand aiming to reduce the electricity bill. Nevertheless, the adjustment of demand is not an easy task since it requires continuously monitoring demand and kWh prices, and simultaneously deciding when to decrease or even increase demand and how. The adjustment of demand should be done through the implementation of demand response actions. The range of demand response actions varies according to the type of load and includes deciding:

- when to turn on laundry machines, tumble dryers, dishwashers;

- the temperature to be set and/or the curtailments to be applied over thermostatically controlled loads, such as air conditioners and electric water heaters or even refrigerators and freezers;

- what to do with the energy produced locally (store/use/sell back to the grid); and,

- how to manage electricity storage devices, including an electric vehicle which may be used in both grid-to-vehicle (G2V) and vehicle-to-grid (V2G) modes [139].

These decisions are not straightforward to the end-user due to all the inputs that have to be checked and the consequences directly arising from the demand response actions, which directly impact on the electricity consumption but also on the end-user perceived dissatisfaction [140,141]. Also, there is the possibility of combining demand response actions depending on the targeted load. For instance, one or more of the previous decisions may be assigned to thermostatically controlled loads, such as cold appliances, air conditioners and electric water heaters, depending on end-users' preferences, flexibility and level of comfort desired. Temperature settings can be re-set, the working cycle can be delayed or anticipated and short interruptions can be implemented. Therefore, taking into account the level of difficulty associated with domestic energy resources control, the adequate choice of demand response actions to be implemented over each manageable load can be done in an automated way through decision support systems. These systems are supposed to simultaneously 
monitor demand, energy prices and local generation and triggering solutions which minimize the electricity bill and end-user's dissatisfaction.

The control of domestic energy resources has been a topic of research for already several years and the methodology selected depends on the targeted loads and on the final aim of the control [142]. Also the potential existent flexibility has been assessed and some pilot studies have already been conducted [143-145]. Evolutionary computation is one of the methodologies which can be used in this context to optimize the use of domestic energy resources through the selection of demand response actions specifically tailored to the end-user profile [146]. It is important to enhance that the cost of operation of a specific load may vary along the day due to a variable tariff structure although the energy requested to the grid might be the same. Therefore, if the end-user has some flexibility regarding loads operation and temperature settings and he/she is willing to accept a small degradation of the quality of the energy service provided if needed, then a decrease in the electricity bill can be obtained either by using electricity in periods of time in which the kWh price is cheaper or because less energy is needed (for the case of thermostatically controlled loads) or even by coordinating the use of storage systems [140].

Although the economic savings for each household may seem reduced, the aggregation of several houses can drive to substantial benefits at national level impacting in the electrical energy chain and contributing to increase the system's overall efficiency, reliability, flexibility and sustainability.

\section{How much energy saving potential in buildings can be achieved by end-use energy behaviors?}

Energy behaviors are recognized as a key factor in promoting end-use energy efficiency in the residential sector, and are also gaining special relevance during the on-going transition to smart grids. However, energy behaviors are still an underexploited resource due to the lack of adequate approaches to address their complexity and difficulty of quantifying behavioral savings [147].

Energy behaviors are people's acts that lead to energy consumption, and include investment, maintenance, and usage behaviors as well as the management and provision of energy resources [148-150]. While investment behaviors comprise the acquisition of new energy consuming equipment, maintenance behaviors include actions to repair, maintain and improve the equipment or the building. Usage behaviors are end-users' daily actions of using buildings and equipment therein installed. Particularly in smart grid contexts, energy behaviors also comprise actions required to manage energy resources [149,151].

Generally, energy behaviors are influenced by personal and contextual factors and different research disciplines address them through distinct, yet complementary, approaches [148,152]. While the social sciences and humanities are focused on exploring the personal and contextual factors leading to the activation of energy behaviors, engineering explores energy consumption as a result of the technical characteristics of equipment and buildings. Economics considers individuals to be 
rational, minimizing cost and maximizing utility in their daily actions, but the stream of behavioral economics recognizes that individuals use heuristics to simplify information processing. Psychology usually addresses the individual perspective, identifying personal determinants and contextual influences to explain or predict energy behaviors. Sociology and other social sciences see energy behaviors as the result of the social context and not a consequence of individual decisions, considering energy behaviors as the outcome of the social organization in which individuals live, such as social rules and lifestyles.

End-users' behavior may significantly impact energy consumption in residential buildings. Modeling techniques such as building energy performance simulation tools have estimated significant savings potential depending on the behavioral dimensions addressed [153]. While adjusting occupancy schedules may originate savings up to $21 \%$, the combination of other behavioral dimensions related with TC (e.g., occupancy, set points, heated area schedule, ventilation and lighting practices, and use of blinds) may increase the savings potential up to $88 \%$ [154-159]. When considering, in addition to the previous dimensions, other energy services utilized within the residential environment (e.g., powering appliances, water heating), the savings potential may even increase. In general, investment energy behaviors have a higher savings potential than usage behaviors, and the behavioral savings potential per energy service is proportional to the energy consumption breakdown [153].

Although a significant behavioral savings potential has been estimated through modeling approaches, these savings are known to be difficult to materialize through the implementation of behavioral change interventions. Overall, behavioral change interventions usually originate savings up to $20 \%$, but this value varies significantly depending on the strategies utilized to promote behavioral changes and on the social, political and economic context [152]. Taking Europe as an example, the most effective interventions include feedback, energy audits, community-based initiatives and the combination of multiple strategies, all originating savings from $5 \%$ to $20 \%$ [160]. However, these results may not be transferable since they have been achieved in the context of interventions with different characteristics (e.g., location, typology, scope, scale and energy policy context).

Furthermore, behavioral savings may also be partially cancelled by rebound effects such as savings being potentially used by the household for increasing consumption of goods and services, including of energy, and to a reduction of energy demand and lowering fuel prices which, in turn, could increase households' energy consumption [161]. Rebound effects have been estimated around 5-13\% for electricity efficiency improvements [162], 6\% for lighting improvements [163], 15-25\% for space cooling and heating improvements [164], and $9 \%$ and $14 \%$ for behavioral changes using electric appliances and heating, respectively [161]. Rebound effects also differ among geographic areas. For example, while in the USA rebound effect was estimated around $56-80 \%$ [165], in Europe this value is only $18.3 \%$ [166].

In summary, end-use energy behaviors may significantly impact residential energy consumption therefore playing an important role in energy efficiency in buildings, although behavioral savings may be limited by real-world constraints and rebound effects. 


\section{Why should indoor environmental quality be integrated in buildings' energy performance assessment?}

As people spend $60-90 \%$ of their time indoors [167,168], Indoor Air Quality (IAQ) is one of the major environmental health concerns in Europe [169,170], and it plays a determining impact on the health of buildings occupants worldwide [171-174], mainly of children and elderly people as they are the most sensitive groups [167].

IEQ is related to IAQ and it is defined in ref. [175] as the complex of thermal, visual, acoustic, vibration and ergonomic comfort and indoor air quality. TC is also a decisive factor for health, comfort and work/study proficiency of people [171,175-178] and significant economic and social costs may arise when it is neglected. TC is defined as the condition of mind which expresses satisfaction with the thermal environment [179]. It can assessed by objective evaluation, and the main factors to be considered are the indoor air temperature, mean radiant temperature, humidity and air velocity [175]. Healy [180] established a relationship between cold indoor environments (related to low construction insulation) and high season mortality in Southern and Western Europe. It is suggested that improved indoor conditions and socioeconomic protection might lead to a decrease in winter mortality in mild winter climates. A good illuminance level also contributes to a suitable indoor environment. In fact, the payback of daylighting goes beyond energy savings. It has been suggested that daylighting improves learning up to $21 \%$ [181]. Besides, from a psychological perspective, it effectively stimulates the human visual and circadian systems as suggested in ref. [170]. For the mentioned reasons, it is mandatory that buildings ensure good IEQ to occupants.

The EE-TC-IAQ Dilemma [182] (Energy Efficiency (EE) along with TC and IAQ) embodies a great task in the buildings' operation and management field. Until recently, the IEQ issues have been approached separately from the EE issues in buildings. This is why many different case-studies are found in literature for each field, but few integrated studies are found. In [183], the authors presented an integrated approach to reduce the energy consumption in school buildings while providing good indoor environmental conditions, and in [184], the IAQ of homes is evaluated considering EE. In fact, it is proposed a reflection on the evolution of the reduction of useful floor space in dwellings and the air tightness and restricted air infiltration, which may lead to internal air change rates reduced by almost $90 \%$ [185]. It is also stated that reducing ventilation rates to improve EE and reduce carbon emissions, without incorporating an effective ventilation strategy, results in a more toxic indoor environment, which is expected to have a long-term impact on public health [184]. Although this issue was mainly addressed towards housing, the same reasoning might be addressed towards spaces were people spend most of their daily time, as offices and schools [186], where poor ventilation rates in classrooms may significantly impair children's attention and vigilance [174].

Within this "dilemma", end-users' behaviors should not be disregarded, as they are determinant for the use of energy. As expressed by Janda [168], buildings do not use energy, people do. Relating TC, besides environmental factors, end-users' behaviors (such as the activity and clothing insulation) also take part of the equation. For example, if the metabolic rate is somehow conditioned by the activity (e.g., seated in an office - sedentary activity, 1.2 met [187]) and it cannot be easily 
altered, the clothing layers may correspond to a significant individual adjustment, i.e. adaptation $[188,189]$. Human adaptation should be one of the main drivers to EE. Lately, due to the increase of mechanical ventilated systems use in buildings, people seem to have tightened their comfort levels. In fact, in countries where HVAC systems are still not so imbedded, or where outdoor conditions go beside the "typical" European ranges, people feel more comfortable (i.e. people state to feel neutral or to accept the experienced conditions) besides the current comfort standards [190-193], such as ISO 7730 [187], ASHRAE 55 [179], EN 15251 [194] or the forthcoming EN 16798. The effort that the standards have been doing to incorporate TC adaptive models in a more sustainable building performance perspective is noteworthy. By enlarging the comfort boundaries, it has been unveiled that it is possible to reach comfort levels in non-mechanical ventilated buildings. Going beyond the 70's approach on energy conservation through building tightness (that led to some of the problems formerly presented, such as increased concentration of pollutants indoors [195]), a different attitude is needed. Besides adaptation, energy unenlightenment seems to be one of the main agents driving against EE in buildings.

Dias Pereira [193] draws attention to "technological illiteracy or sins of emission", relating the miss-control of building management systems in secondary schools, e.g. recalling the need for postoccupancy evaluation actions [196], vital analyses to identify opportunities for fine tuning of the systems operation. Basically, better building management systems operation and scheduling are suggested, along with passive measures towards IEQ when systems are turned off (e.g., due to energy constraints). Herein again, adaptive actions such as windows and/or doors opening are determinant, aiming at raising the ventilation rates and lowering $\mathrm{CO}_{2}$ concentration levels. Chenari et al. [197] reinforced the importance of different ventilation methods and control strategies on energy consumption. Aste et al. [198] also reinforced the importance of proper management of 'Building Automation and Control Systems (BACS) for performance optimization'.

Finally, we recall the suggestion of including energy public education on building literacy (e.g., reinforcing curricula of non-engineering subjects addressing the energy issue) $[168,199,200]$. The author also suggested that such education (on energy) could start in school $[168,199,200]$. Examples of Living labs, such as the $\mathrm{I} 2 \mathrm{~L}$ - being developed at the Mechanical Engineering Department of the University of Coimbra [201], represent significant strategies headed for "research and technology demonstration in IEQ", which allow improving EE through testing of different types of behavioral strategies as recommended by Janda [168]. Soares et al. [202] highlighted the importance of engaging students, faculty and office staff for working together on the assessment of the EE of higher education buildings. The authors also pointed out that the higher education sector holds important functions in educating the next generation of professionals for a sustainable culture. 


\section{How can generative design methods contribute to the improvement of buildings' performance?}

Generative design methods have been increasingly used in building design, namely in areas such as engineering design, urban planning and architectural design. Such methods consist in automatic procedures to create alternative design solutions that satisfy a set of criteria, or to fit given parts into a coherent whole [203,204]. These comprise algorithmic approaches that take advantage of the immense working capability of computers to create a large number of solutions that would otherwise be impossible to obtain [205]. The most common methods are shape grammars, evolutionary computation, and local search techniques, which can be used at different scales of design, for instance urban design [206,207], building design [208-210], façade design [211,212], space planning [213,214], structural design [215], construction element design [216], and furniture arrangement [217,218].

With the change of the building design paradigm from "form follows function" to "performancebased" design [219-221], simulation programs have been used together with these methods to assess the energy consumption, TC, visual comfort and indoor air quality of the generated solutions. The basic idea is that, for the same building function there are several different possible performances, each with a corresponding building design. Therefore, if alternative solutions are generated, these can be assessed to find the best possible performance by using certain estimation mechanisms such as dynamic simulation. Furthermore, we can explore each solution's potential for improvement by using some sort of optimization technique (i.e. the fine tuning of the design solution) [222-224].

The ideal approach would be to have performance estimation incorporated in the generation process that includes all scales and energy systems in a holistic manner; however, certain issues arise such as:

- design procedural problem - the current building design process is essentially a sequential approach where the level of detail increases right up to the end. This kind of approach limits the possibility of major changes in the building design in the final stages of the process. The order in which these changes are carried out also contributes to the effectiveness of the final solution. At this point in time, generative design methods tackle specific stages of the building design process. For example, this means that the choice of determining the building form before knowing the arrangement of the interior space may result in the discarding of other potential solutions [225]. However, if generative methods simultaneously include several tasks criteria, the optimum global design solution would be closer to being found;

- designer's preferences - architectural design is a creative process where preferences are difficult to quantify and formulate. Design preferences also vary in time and among practitioners. In other words, the main obstacle to a holistic automated procedure is the ability to correctly capture a number of minimal designer's preferences [226];

- combinatorial problem - buildings are complex systems with competing aspects that contribute to their performance. Basically, it is very hard - if not impossible - to find a solution that satisfies all the initial design criteria. The best design, known as the optimum solution, is not found by 
determining the ideal value of each parameter but instead by finding a compromise between all parameters. With the increase in the complexity of the problem the results grow exponentially and therefore these are more computationally demanding. Population-based methods are the most promising methods [227], as these can globally search the solution space, thus reducing the possibility of becoming entrenched in a local minimum;

- model accuracy - despite dynamic simulation being a powerful tool, accurate estimation of the building behavior depends on detailed simulation models and their validation. However, in the initial design phase, practitioners only have a vague idea of the different building aspects such as the final design program, constructive system, materials, building geometry, equipment, and so on [228]. Therefore, the way to overcome this problem would be to use databases of typified spaces, occupancies, activities, equipment levels, and other performance-related information that could be invoked by the generative method; and,

- computation intensity - the more complex and detailed the dynamic simulation model, the more computation time will be required to perform accurate performance estimations. The problem increases due to the cyclic nature of generative methods and optimization procedures. However, this issue can be mitigated by using surrogate methods (e.g., artificial neural networks) $[229,230]$.

The contribution of generative design methods to the improvement of the building performance depends on the appropriateness and reliability of the generated solutions. More integrated and comprehensive methods deal with more robust and efficient building solutions. In addition to helping building practitioners in overcoming specific design tasks, these methods can also contribute indirectly to the understanding of a building's performance by creating large synthetic datasets that may be used to either statistically deduce particular building phenomena [231,232], or develop surrogate methods for the dynamic simulation programs.

\section{What are the different methodologies for the assessment of building retrofit actions?}

The works involved in retrofit are usually of complex and heterogeneous nature that require various specialties to be integrated in highly variable conditions. Furthermore, a thorough building's retrofit evaluation is quite difficult to undertake, because a building and its environment are complex systems regarding technical, technological, ecological, social, comfort, esthetical, and other aspects, where every sub-system influences the total efficiency performance and the interdependence between subsystems plays a critical role [233]. There are a number of models and methods developed to assess conditions and support decisions pertaining to building retrofit. These methodologies can be categorized into two main approaches: the models in which alternative retrofit solutions are explicitly known a priori (e.g., see [234-237]) and the models in which alternative retrofit solutions are implicitly defined in the setting of an optimization model (e.g., see [238-241]).

The most common a priori approach is one in which the decision maker assigns weights to each criterion, the weighted sum of the criteria then forming a single design criterion. It is then possible to find the single design solution that optimizes the weighted sum of the criteria. Gero et al. 
[234] were among the first to propose a multi-criteria analysis model to be used at the process of building design in order to explore the trade-offs between the building thermal performance and other criteria such as capital cost and usable area. More recently, other researchers have also employed multi-criteria analysis techniques to similar problems. Jaggs and Palmer [235], Flourentzou and Roulet [236], and Rey [237] proposed approaches for the evaluation of retrofitting scenarios. Kaklauskas et al. [233] developed a multivariate design method and multi-criteria analysis for building retrofit, determining the significance, priorities and utility degree of building retrofit alternatives and selecting the most recommended variant. These lines of research have allowed addressing many problems as far as buildings retrofit is concerned. However, most of them consider that a list of predefined and preevaluated alternative variants of the building retrofit options is given. In case a small number of such solutions have been defined, there is no guarantee that the solution finally reached is the best one (from the decision maker's perspective). On the opposite case, when a large number of solutions are defined the required evaluation and selection process may become extremely difficult to handle. Moreover, multi-criteria analysis-based methodologies do not provide the designer with information about how sensitive each criterion is to changes of the other criteria [242].

The second approach, based on multi-objective optimization, enables to consider a large set of building retrofit options implicitly defined by the constraints defining the search space and grasp the trade-offs between the objective functions helping to reach a satisfactory compromise solution. However, so far, relatively little attention has been paid to tackling building retrofit decision support with multiple objective optimization [243]. Diakaki et al. [239] investigated the feasibility of applying multi-objective optimization techniques to the problem of improving energy efficiency in buildings, considering a simplified model for building thermal simulation. Asadi et al. [240] proposed a multiobjective optimization model that supports the definition of retrofit actions aimed at minimizing energy use in a cost effective manner. Following this work, they developed a multi-objective optimization model combined with TRNSYS (building performance simulation program) and GenOpt (an optimization program). The proposed model was used for the optimization of retrofit cost, energy savings, and TC of a residential building, in a framework of a multi-objective optimization model [238].

Considering all the possibilities that the decision maker has available for building retrofit (e.g., HVAC systems and renewable energy sources), as well as all the objectives that one may wish to optimize $\left(\mathrm{CO}_{2}\right.$ emissions, social objectives, etc.), it may lead to the combinatorial explosion of the decision problem, thus making the solving procedure extremely difficult and time-consuming. In such case, other optimization techniques, namely multi-objective genetic algorithms are necessary for tackling the problem. Wright et al. [244] used a multi-objective genetic algorithms to find the trade-offs between the energy cost and TC for the design of a single zone HVAC system. Hamdy et al. [245] proposed a multi-objective optimization approach based on genetic algorithms to tackle the problem of designing low-emission cost-effective dwellings, minimizing the carbon dioxide emissions and the investment cost for a two-story house and its HVAC system.

A main drawback of genetic algorithms is the high burden whenever it is necessary to make a large number of calls to an evaluation function involving a high computational cost. In building 
applications, these evaluations are generally estimated by an external simulation program such as Computational Fluids Dynamics or other simulation packages. If accurate results are required, each evaluation can be time consuming, and thus the complete computational process becomes extremely unattractive [229]. Accordingly, building optimization studies using genetic algorithms generally tend to reduce the computational time by using two methods. The first method consists in using very simplified models instead of complex simulation software [246]. However, this method presents a risk of over-simplification and inaccurate modeling of building phenomena. The second method commonly used is to select very small genetic algorithms populations and/or relatively small number of generations [247]. Again, the optimization can be significantly affected and may lead to narrow or nonoptimal solution sets [248].

One very efficient, yet not widely exploited, solution to reduce the computational time associated with genetic algorithms is to use a response surface approximation model to first mimic the behavior of the base building model, and then use this response surface approximation inside the genetic algorithms for the evaluation of individuals [229]. By doing so, the computational time associated with each evaluation becomes negligible, while a good accuracy is maintained in the results. While several response surface approximation methods exist, there is no common agreement regarding which technique is best [249].

\section{How can thermal energy storage systems with PCMs improve buildings' energy performance?}

Thermal energy storage (TES) systems with PCMs can be used to: reduce buildings' dependency on fossil fuels; make use of renewable energy sources; improve the thermal resistance and heat capacity of building's envelope; improve indoor TC; reduce the energy demand for heating and cooling; and to reduce the air-conditioning power needed and heating/cooling peak-loads. Compared to traditional materials used in construction, PCMs provide a large heat capacity over a limited temperature range (due to high energy quantities involved in the solid-liquid phase-change processes) and they could act like an almost-isothermal reservoir of heat. As the temperature increases and reaches the meltingtemperature, PCMs change phase from solid to liquid absorbing heat. When the temperature decreases and reaches the solidifying-temperature, PCMs change phase from liquid to solid releasing the stored heat. The PCM-based systems are commonly pooled into two main groups: passive and active systems. Here, "passive" means that the phase-change processes occur without resorting to mechanical equipments.

Regarding the problem of liquid leakage, several ways of containment and different techniques for incorporating PCMs in construction materials have been studied. Two of the most well-known techniques are the microencapsulation and the macroencapsulation techniques. In the former, the PCM is encapsulated within a micropolymeric capsule. The final result is a powder-like material that can be mixed with other materials (e.g., gypsum and cement mortars). In the latter, the macrocapsule may be the only way of confinement. These macrocapsules are typically made of high-conductivity 
materials in order to enhance the heat transfer to the PCM-bulk, as PCMs have typically low thermal conductivity [250].

The principles of PCMs' use are simple; however, optimizing the incorporation of PCMs within passive TES systems and evaluating the energy performance of the building with these elements is very complex and challenging. This entails including the use of the building and the typology of construction (high or low thermal inertia) and the major design parameters, namely the phase-change temperature of the PCM and its quantity. Moreover, such parameters need to be specified for given indoor loads and also for specific climatic conditions. Regarding the incorporation of PCMs in active systems, similar challenges are expected. However, in this case, the heat supply control may allow better control of phase-change processes.

The number of articles concerning the integration of PCMs in buildings has been increasing during the last decade. The research topics range from the most general to very specific ones, covering issues such as: the kind of PCMs and the main criteria for their selection [251-266]; the thermophysical properties of different PCMs $[253,255-260,263,265,267,268]$ and the main techniques for their measurement [251,256,269-273]; the long-term stability of PCMs [257,259,271,274]; the hysteresis and subcooling problems [259,273,275]; the different techniques for encapsulation and containment [262,264,265,271,276-281], including microencapsulation [282-286]; the description of PCM emulsions [287] and PCM slurries [284,287,288]; the description of several impregnation methods [251]; the main properties of shape-stabilized PCMs [289]; the combination of thermal insulation and TES properties [290]; the description of some heat transfer enhancement techniques [251,259,268,276,291-293]; the mathematical and numerical modeling of phase-change problems [276,294-299]; the description of several applications for buildings and their thermal performance analysis [251,254,258,261,264,267,271,272,279,286,291,300-311]; the dynamic simulation of energy in buildings with PCMs [251,295,312-314]; the free-cooling of buildings with PCM-based systems [277,303,315-317]; the design of ventilation and air-conditioning systems with PCMs [291,316,318,319] and other active systems for buildings [267,271,301,303,320]; the integration of PCMs in domestic hot water systems [321,322]; the latent heat storage in solar collectors [323,324] and other solar systems [254,268,324-326]; the thermal management of photovoltaics [327-333]; the thermal control of electronic devices [254,292]; the exergy assessment [334] of PCM-based systems; the use of PCMs for cold storage applications [335] and other TES applications [266,336,337].

Many of these papers pointed out that the study of solid-liquid phase-change of PCMs is of great interest from the theoretical point of view and for the development of new TES systems. Moreover, several research gaps were identified and some recommendations for future work were noted, such as:

- the design of new passive/active TES systems to take advantage of solar energy or other renewable sources;

- the assessment of the stability and convergence of numerical results, and the importance of validating the numerical predictions using appropriated experimental data (together with a suitable uncertainty analysis); 
- the importance of the effects of hysteresis, subcooling and natural convection phenomena in the simulations and the challenging assessment of the thermophysical properties of PCMs and PCM-based elements in small, medium and large samples;

- the economic and the environmental life-cycle assessment of PCM-based systems; and,

- the development of methodologies to couple dynamic simulation of energy in buildings techniques with multi-dimensional, multi-criteria and/or multi-objective optimization analysis to help decision-making in the optimization of the configuration of TES systems, their functioning and their location within the building.

\section{How can HVAC fluids and transport fluid movers improve buildings' overall energy efficiency?}

During the last decades, significant advances in HVAC transport and working fluids have been emerging to overcome environmental issues, despite other major concerns on their thermophysical and safety properties, chemical stability, working pressure range, availability, cost and toxicity [338,339]. Indeed, restrictions on both ozone depletion and global warming potentials, respectively ODP and GWP, have been tracing guidelines for the development of new refrigerants [338-344]. As suggested by Kilicarslan and Muller [345], water holds a prominent place in HVAC applications. It is an adequate candidate for energy carriage or storage because of its reliability, stability, low cost, high latent capacity, specific heat and density, safety and appropriate fusion temperature [346]. However, its thermal conductivity is much lower than that of the most metals or metal oxides. The addition of solid particles into a liquid-water base has been a current practice, but the early versions of colloidal fluids tend to sediment and cause erosion of the fluid mover $[347,348]$. The overall energy transport capability of the fluid can also be enhanced by using nanofluids [349], an engineered colloidal mixture of the base fluids and nano-sized metallic particles [347,350]. Many pure metal and metal oxide nanoparticles have been tested, using water, pure or mixed with ethylene glycol (an aqueous freezing point depressant) $[347,351,352]$. Experiments have shown promising results when using nanofluids as transport fluids, namely on the reduction of the volume and mass flow rates, and on the reduction of the heat surface area and heat exchanger material volume, although the proportional increment of viscosity on the nanoparticles volume concentration [349,351,353-356]. Applications of $\mathrm{Al}_{2} \mathrm{O}_{3}, \mathrm{CuO}$, $\mathrm{TiO}_{2}$ and silver nanofluids as working fluids, evidence an enormous potential in HVAC dehumidification processes, when coupled with thermosiphon heat exchangers [356]. On the other hand, from the energy consumption point of view, $\mathrm{SiO}_{2}$ mixtures are more adequate for heating processes [354].

PCMs slurries (with microencapsulated PCMs) can also be used to enhance heat-transfer. Indeed, this slurries have been identified as a thermal storage media and a heat transfer fluid, having potential applications in HVAC, refrigeration and heat exchangers [357-362]. When compared to conventional heat transfer fluids, PCM-based slurries have higher specific heat and TES capacity [363], with a small temperature difference between storing and releasing heat. Similarly to nanofluids, and due to phase change, the heat transfer enhancement decreases volume and mass flow rates, 
although the increment on the pressure drop. As discussed in the section above, TES with solid-liquid phase change has been a major topic in energy-saving research [255,360,364]. In this field, some problems as the low thermal conductivity (especially in the liquid state) and the solidification and subcooling times were surpassed gathering nanotechnology techniques; by dispersing the multi wall carbon nanotubes, in pure water PCM, resulting in 6 to $9 \%$ of energy-saving potential in water chiller system [365]. Encouraging results were also achieved in other direct applications of latent storage in ventilation and air-conditioning equipment [362,364], such as:

- the integration of PCM in heating storage tanks,

- packed bed PCM storage used in ventilation ductwork for free cooling enhancement,

- storage units for night-cold-air charging and discharging during the day to absorb heat gains; and,

- ice slurries lowering temperature and reducing cold air distribution systems and energy consumption.

It should be pointed out that using ice storage in water-based systems may have some drawbacks, as the cold water supply has to be produced at lower temperatures, reducing the chiller coefficient of performance (COP). Nevertheless, operating in night-time mode and having a latent heat storage with a relatively high melting temperature $\left(10^{\circ} \mathrm{C}\right)$, it can improve the theoretical COP by almost $80 \%$, despite of the impacts on the heat dissipation rate of the terminal units and the impossibility of using dehumidification by cooling air below the dew point temperature [366].

Regarding energy transport systems, they are frequently classified in two- (e.g., refrigerant) and single-phase (e.g., water and glycol) fluid/liquid piping, and air duct systems [367]. This classification distinguishes the effectiveness of the energy transportation, from the most to the least efficient system [367]. For these systems, energy-efficiency requirements are based on low distribution losses and reduced energy consumption of fluid movers, such as compressors, pumps and fans [368]. Their consumption is directly proportional to the volume flow rate, specific consumption and operating period, expressed in terms of equivalent full load hours [368]. As mentioned, volume and mass flow rates can be reduced with the inclusion of energy carriage enhancers in transport and working fluids, as nanofluids and PCMs. Specific consumption requirements are applicable to fans and pumps power limitation [368], but current technologies and an adequate strategy easily surpass this problem, such as including equipment with electronic variable speed or frequency drives, defining adequate setpoint and control strategies for chillers, heat exchangers and pumps, etc. [369-371]. Such measures, allied to the "peak shifting" or "peak shaving" on thermal loads provided by TES [364], allows to reduce not only the specific consumption, but also the equipment operating period. Thus, the combination of all these measures, lowering each factor, reduces the energy consumption of the fluid movers. 


\section{Conclusions}

This paper reviews ten selected research topics on the improvement of the energy and environmental performance of buildings. The topics (addressed as research questions) are discussed, drawing on a summarized background and state of the art literature review for each topic. The selected topics cover different stages of the lifetime of buildings, scale approaches, and methodologies to evaluate the energy and environmental performance of buildings, providing a holistic perspective of the complexity of evaluating the dynamics of buildings. Research gaps and opportunities are also presented. While a more detailed review within a single topic might be potentially useful, this paper brings together multidisciplinary research, which is currently fragmented in literature, and in general practice. The gaps and opportunities identified highlight the potential and need for integrating research and methods to better support decision-making towards a more sustainable built environment.

Addressing each of the ten research questions, this review highlights that:

- LCA allows identifying the most significant life cycle phase and processes in a building for a diversity of environmental impacts, which helps focused and efficient improvements in key processes while preventing problem-shifting. This comprehensive methodology has been widely applied to buildings; however, due to the complexity and uncertainty associated with these systems, significant challenges should be addressed in future research, including how to model unpredictable data, such as: the systems adopted, the end-users behavior (systems operation), the maintenance and service life and the building dismantling and end-of-life.

- Design, location and local urban characteristics affect the environmental performance of buildings, and focusing on the individual building alone might neglect potential interactions with the urban scale, shift impacts and overlook improvement opportunities for a more sustainable urban development. More research is needed to explore the linkages of urban form, buildings and transportation environmental performance, in a holistic perspective, to better inform and support decision-making.

- The NZEB concept has been widely studied; however, slight attention has been given to groups of buildings in the urban context. District scale approaches aim to gather the study of buildings and urban characteristics that may influence their energy performance. It is important to better understand the interaction between buildings and urban context, and to consolidate the potential benefits of sharing resources and energy systems at this scale.

- The control of energy resources in a smart grid scenario where the existence of dynamic tariffs (variable in amplitude and along the day) is a reality that can be done in an efficient way through the use of decision support systems, such as energy management systems endowed with adequate optimization algorithms.

- Energy behaviors are an important underexploited resource in the context of promoting end-use energy efficiency in the residential sector, and the potential of energy savings can be as significant as those from technological solutions.

- As people spend most of their time indoors, IEQ is a key issue on people's life. Besides human comfort in general, indoor conditions such as ventilation requirements strongly influence the 
energy consumption in buildings. More education is demanded on the energy subject to improve the energy performance and the IAQ of buildings.

- When coupled with a performance assessment mechanism, generative design methods can contribute to the improvement of building's design by producing a number of alternative solutions to be compared by the building practitioner, by integrating different design aspects that otherwise would be assessed individually, and by creating large datasets of synthetic data to analyze the general buildings behavior in specific contexts.

- The methodologies for assisting decision making in the appraisal of retrofit actions according to multiple, generally conflicting evaluation aspects may be distinguished into two main approaches: first, approaches in which alternatives are explicitly known a priori and second, models in which alternatives are implicitly defined in the setting of an optimization model. More research has to be carried out to generalize the use of multi-objective methodologies for the assessment of building retrofit actions.

- Active and passive PCM-based TES systems can be used in buildings to improve the use of renewables and to reduce the energy demand for heating and cooling. However, there is still a long way for the generalized use of PCM-based systems in design and retrofitting strategies, and more research has to be carried out in these research fields.

- Further theoretical and experimental research has to be carried out to optimize HVAC fluids, transport fluid movers, control strategies and energy management to enhance buildings' overall energy efficiency.

\section{Acknowledgment}

This work has been framed under the Initiative Energy for Sustainability of the University of Coimbra and the Sustainable Energy Systems focus area of the MIT-Portugal Program. It was partially supported by Fundação para a Ciência e a Tecnologia (FCT) under grants SFRH/BD/51640/2011, SFRH/BD/52309/2013， SFRH/BD/77105/2011， SFRH/BD/88127/2012, $\quad$ PD/BD/113718/2015, SFRH/BPD/94385/2013, SFRH/BPD/99668/2014, SFRH/BD/33736/2009, SFRH/BD/51104/2010, and projects MITP-TB/CS/0026/2013 and UID/MULTI/00308/2013. The work has also been funded by FEDER funds through the COMPETE 2020-POCI, and by FCT in the framework of the projects POCI01-0145-FEDER-016750 | PTDC/EMS-ENE/6079/2014 and PTDC/SEM-ENE/3238/2014 | POCI-010145-FEDER-016760 | LISBOA-01-0145-FEDER-016760.

\section{References}

[1] European Union. Smarter, greener, more inclusive? - Indicators to support the Europe 2020 strategy. Eurostat 2015.

[2] EPBD (recast), Directive2010/31/EU of the European Parliament and of the Council of 19 May 2010 on the energy performance of buildings (recast), in Official Journal of the European Union (2010), L153/13-153/35. 
[3] Guinée J. Handbook on life cycle assessment - operational guide to the ISO standards. The International Journal of Life Cycle Assessment 2001;6(5):255-255.

[4] ISO-14040 Environmental Management-Life Cycle Assessment-Principles and Framework, 2006.

[5] ISO-14044 Environmental Management-Life Cycle Assessment- Requirements and Guidelines, 2006.

[6] Gustavsson L, Sathre R. Variability in energy and carbon dioxide balances of wood and concrete building materials. Building and Environment 2006;41(7):940-51.

[7] Ximenes FA, Grant T. Quantifying the greenhouse benefits of the use of wood products in two popular house designs in Sydney, Australia. The International Journal of Life Cycle Assessment 2013;18(4):891-908.

[8] Dodoo A, Gustavsson L, Sathre R. Effect of thermal mass on life cycle primary energy balances of a concrete- and a wood-frame building. Applied Energy 2012;92:462-72.

[9] Gerilla GP, Teknomo K, Hokao K. An environmental assessment of wood and steel reinforced concrete housing construction. Building and Environment 2007;42(7):2778-84.

[10] Tingley DD, Hathway A, Davison B. An environmental impact comparison of external wall insulation types. Building and Environment 2015;85:182-9.

[11] Shrestha SS, Biswas K, Desjarlais AO. A protocol for lifetime energy and environmental impact assessment of building insulation materials. Environmental Impact Assessment Review 2014;46:25-31.

[12] Tettey UYA, Dodoo A, Gustavsson L. Effects of different insulation materials on primary energy and CO2 emission of a multi-storey residential building. Energy and Buildings 2014;82:369-77.

[13] Papadopoulos AM, Giama E. Environmental performance evaluation of thermal insulation materials and its impact on the building. Building and Environment 2007;42(5):2178-87.

[14] Mazor MH, Mutton JD, Russell DAM, Keoleian GA. Life cycle greenhouse gas emissions reduction from rigid thermal insulation use in buildings. Journal of Industrial Ecology 2011;15(2):284-99.

[15] Monteiro H, Freire F. Life-cycle assessment of a house with alternative exterior walls: comparison of three impact assessment methods. Energy and Buildings 2012;47:572-83.

[16] Silvestre JD, de Brito J, Pinheiro MD. From the new European Standards to an environmental, energy and economic assessment of building assemblies from cradle-to-cradle (3E-C2C). Energy and Buildings 2013;64:199-208.

[17] Baglivo C, Congedo PM, Fazio A. Multi-criteria optimization analysis of external walls according to ITACA protocol for zero energy buildings in the mediterranean climate. Building and Environment 2014;82:467-80.

[18] Aldawi F, Alam F, Date A, Alghamdi M, Aldhawi F. A new house wall system for residential buildings. Energy and Buildings 2013;67:403-18.

[19] Iribarren D, Marvuglia A, Hild P, Guiton M, Popovici E, Benetto E. Life cycle assessment and data envelopment analysis approach for the selection of building components according to their environmental impact efficiency: a case study for external walls. Journal of Cleaner Production 2015;87:707-16.

[20] Islam H, Jollands M, Setunge S, Ahmed I, Haque N. Life cycle assessment and life cycle cost implications of wall assemblages designs. Energy and Buildings 2014;84:33-45.

[21] Hens H, Janssens A, Depraetere W, Carmeliet J, Lecompte J. Brick cavity walls: a performance analysis based on measurements and simulations. Journal of Building Physics 2007;31(2):95-124.

[22] Frenette CD, Bulle C, Beauregard R, Salenikovich A, Derome D. Using life cycle assessment to derive an environmental index for light-frame wood wall assemblies. Building and Environment 2010;45(10):2111-22. 
[23] Kosareo L, Ries R. Comparative environmental life cycle assessment of green roofs. Building and Environment 2007;42(7):2606-13.

[24] Yasantha Abeysundra UG, Babel S, Gheewala S. A decision making matrix with life cycle perspective of materials for roofs in Sri Lanka. Materials \& Design 2007;28(9):2478-87.

[25] Rodrigues C, Freire F. Integrated life-cycle assessment and thermal dynamic simulation of alternative scenarios for the roof retrofit of a house. Building and Environment 2014;81:204-15.

[26] Gervásio H, Santos $P$, Martins R, Simões da Silva L. A macro-component approach for the assessment of building sustainability in early stages of design. Building and Environment 2014;73:256-70.

[27] Xing S, Xu Z, Jun G. Inventory analysis of LCA on steel- and concrete-construction office buildings. Energy and Buildings 2008;40(7):1188-93.

[28] Kofoworola OF, Gheewala SH. Life cycle energy assessment of a typical office building in Thailand. Energy and Building 2009;41(10):1076-83.

[29] Scheuer C, Keoleian GA, Reppe P. Life cycle energy and environmental performance of a new university building: modeling challenges and design implications. Energy and Buildings 2003;35(10):1049-64.

[30] Dahlstrøm O, Sørnes K, Eriksen ST, Hertwich EG. Life cycle assessment of a single-family residence built to either conventional- or passive house standard. Energy and Buildings 2012;54:470-9.

[31] Dodoo A, Gustavsson L, Sathre R. Lifecycle carbon implications of conventional and lowenergy multi-storey timber building systems. Energy and Buildings 2014;82:194-210.

[32] Verbeeck $G$, Hens $H$. Life cycle optimization of extremely low energy dwellings. Journal of Building Physics 2007;31(2):143-77.

[33] Blengini GA, Carlo TD. The changing role of life cycle phases, subsystems and materials in the LCA of low energy buildings. Energy and Buildings 2010;42(6):869-80.

[34] Dodoo A, Gustavsson L, Sathre R. Lifecycle primary energy analysis of low-energy timber building systems for multi-storey residential buildings. Energy and Buildings 2014;81:84-97.

[35] Bastos J, Batterman SA, Freire F. Life-cycle energy and greenhouse gas analysis of three building types in a residential area in Lisbon. Energy and Buildings 2014;69:344-53.

[36] Proietti S, Sdringola P, Desideri U, Zepparelli F, Masciarelli F, Castellani F. Life Cycle Assessment of a passive house in a seismic temperate zone. Energy and Buildings 2013;64:463-72.

[37] Monteiro H, Fernández JE, Freire F. Comparative life-cycle energy analysis of a new and an existing house: the significance of occupant's habits, building systems and embodied energy. Sustainable Cities and Society 2016;26:507-18.

[38] Gaspar PL, Santos AL. Embodied energy on refurbishment vs. demolition: a southern Europe case study. Energy and Buildings 2015;87:386-94.

[39] de Larriva RA, Rodríguez GC, López JMC, Raugei M, i Palmer PF. A decision-making LCA for energy refurbishment of buildings: conditions of comfort. Energy and Buildings 2014;70:33342.

[40] Nicolae B, George-Vlad B. Life cycle analysis in refurbishment of the buildings as intervention practices in energy saving. Energy and Buildings 2015;86:74-85.

[41] Dodoo A, Gustavsson L, Sathre R. Life cycle primary energy implication of retrofitting a woodframed apartment building to passive house standard. Resources, Conservation and Recycling 2010;54(12):1152-60.

[42] Vilches A, Garcia-Martinez A, Sanchez-Montañes B. Life cycle assessment (LCA) of building refurbishment: a literature review. Energy and Buildings 2017;135:286-301.

[43] Rodrigues C, Freire F. Environmental impact trade-offs in building envelope retrofit strategies. The International Journal of Life Cycle Assessment 2016:1-14. 
[44] Stephan A, Crawford $\mathrm{RH}$, de Myttenaere K. A comprehensive assessment of the life cycle energy demand of passive houses. Applied Energy 2013;112:23-34.

[45] Ramesh T, Prakash R, Shukla KK. Life cycle energy analysis of a residential building with different envelopes and climates in Indian context. Applied Energy 2012;89(1):193-202.

[46] Gustavsson L, Joelsson A, Sathre R, Life cycle primary energy use and carbon emission of an eight-storey wood-framed apartment building. Energy and Buildings 2010;42(2):230-42.

[47] Dodoo A, Gustavsson L. Life cycle primary energy use and carbon footprint of wood-frame conventional and passive houses with biomass-based energy supply. Applied Energy 2013;112:834-42.

[48] Kneifel J. Life-cycle carbon and cost analysis of energy efficiency measures in new commercial buildings. Energy and Buildings 2010;42(3):333-40.

[49] Monteiro H, Freire F. Environmental life-cycle impacts of a single-family house in Portugal: assessing alternative exterior walls with two methods. Gazi University Journal of Science $2011 ; 24(3): 527-34$.

[50] Ortiz-Rodríguez O, Castells F, Sonnemann G. Life cycle assessment of two dwellings: One in Spain, a developed country, and one in Colombia, a country under development. Science of the Total Environment 2010;408(12):2435-43.

[51] Buyle M, Braet J, Audenaert A. Life cycle assessment in the construction sector: a review. Renewable and Sustainable Energy Reviews 2013;26:379-88.

[52] Cabeza LF, Rincón L, Vilariño V, Pérez G, Castell A. Life cycle assessment (LCA) and life cycle energy analysis (LCEA) of buildings and the building sector: a review. Renewable and Sustainable Energy Reviews 2014;29:394-416.

[53] Chau CK, Leung TM, Ng WY. A review on life cycle assessment, life cycle energy assessment and life cycle carbon emissions assessment on buildings. Applied Energy 2015;143:395-413.

[54] Islam $H$, Jollands $M$, Setunge $S$. Life cycle assessment and life cycle cost implication of residential buildings - a review. Renewable and Sustainable Energy Reviews 2015;42:12940.

[55] Zuo J, Pullen S, Rameezdeen R, Bennetts H, Wang Y, Mao G, Zhou Z, Du H, Duan H. Green building evaluation from a life-cycle perspective in Australia: a critical review. Renewable and Sustainable Energy Reviews 2017;70:358-68.

[56] Cuéllar-Franca RM, Azapagic A. Environmental impacts of the UK residential sector: life cycle assessment of houses. Building and Environment 2012;54:86-99.

[57] Gustavsson L, Joelsson A. Life cycle primary energy analysis of residential buildings. Energy and Buildings 2010;42(2):210-20.

[58] Verbeeck $\mathrm{G}$, Hens $\mathrm{H}$. Life cycle inventory of buildings: a contribution analysis. Building and Environment 2010;45(4):964-967.

[59] Pal SK, Takano A, Alanne K, Palonen M, Siren K. A multi-objective life cycle approach for optimal building design: a case study in finnish context. Journal of Cleaner Production 2017;143:1021-35.

[60] Sunikka-Blank M, Galvin R. Introducing the prebound efect: the gap between performance and actual energy consumption. Building Research and Information 2012;40(3):260-73.

[61] Galvin R. Making the 'rebound effect' more useful for performance evaluation of thermal retrofits of existing homes: defining the 'energy savings deficit' and the 'energy performance gap'. Energy and Buildings 2014;69:515-24.

[62] CEN/AFNOR Normalisation, CEN/TC 350 - Sustainability of construction works, 2015.

[63] CEN, EN 15978 - Sustainability of construction works. Assessment of environmental performance of buildings, calculation method. Brussels, 2011.

[64] Kellenberger D, Althaus H-J, Künniger T, Lehmann M, Jungbluth N, Thalmann P. Life cycle inventories of building products. Final report ecoinvent Data v2.0 No7, Dübendorf, CH, 2007. 
[65] Hischier R, Althaus H-J, Bauer C, Doka G, Frischknecht R, Jungbluth N, Nemecek T, Simons A, Stuchi M, Sutter J, Tuchschmid M. in: Documentation of changes implemented in ecoinvent data v2.1 and v2.2. Swiss Centre for Life Cycle Inventories, Dübendorf, 2010.

[66] Silvestre JD, Lasvaux S, Hodková J, de Brito J, Pinheiro MD. Native LCA - a systematic approach for the selection of environmental datasets as generic data: application to construction products in a national context. International Journal of Life Cycle Assessment 2015;20(6):731-50.

[67] Salazar J, Meil J. Prospects for carbon-neutral housing: the influence of greater wood use on the carbon footprint of a single-family residence. Journal of Cleaner Production 2009;17(17):1563-71.

[68] Rossi B, Marique A-F, Reiter S. Life-cycle assessment of residential buildings in three different European locations, case study. Building and Environment 2012;51:402-07

[69] Rickwood P, Glazebrook G, Searle G. Urban structure and energy - a review. Urban Policy and Research 2008;26(1):57-81.

[70] Norman J, Maclean HL, Asce M, Kennedy CA. Comparing high and low residential density: lifecycle analysis of energy use and greenhouse gas emissions. Journal of Urban Planning and Development 2006;132(1):10-21.

[71] Heinonen J, Junnila S. Residential energy consumption patterns and the overall housing energy requirements of urban and rural households in Finland. Energy and Buildings 2014;76:295-303.

[72] Fuller RJ, Crawford RH. Impact of past and future residential housing development patterns on energy demand and related emissions. Journal of Housing and the Built Environment $2011 ; 26(2): 165-83$.

[73] Stephan A, Crawford RH, de Myttenaere K. Multi-scale life cycle energy analysis of a lowdensity suburban neighbourhood in Melbourne, Australia. Building and Environment 2013;68:35-49.

[74] Heinonen J, Junnila S. A carbon consumption comparison of rural and urban lifestyles. Sustainability 2011;3(8):1234-49.

[75] Cervero R, Duncan M. Which reduces vehicle travel more: jobs-housing balance or retailhousing mixing?. Journal of the American Planning Association 2006;72(4):475-90.

[76] Krizek KJ. Residential relocation and changes in urban travel: does neighborhood-scale urban form matter?. Journal of the American Planning Association 2003;69(3):265-81.

[77] Reinhart CF, Dogan T, Jakubiec JA, Rakha T, Sang A. UMI - an urban simulation environment for building energy use, daylighting and walkability. in: Proceedings of BS2013 - 13th Conference of International Building Performance Simulation Association, Chambéry, France, August 26-28, 2013, pp. 476-483.

[78] Nasrollahi N, Shokri E. Daylight illuminance in urban environments for visual comfort and energy performance. Renewable and Sustainable energy Reviews 2016;66:861-74.

[79] Niemasz J, Sargent J, Reinhart CF. Solar zoning and energy in detached residential dwellings. Environ Plan B Plan Des 2013;40(5):801-13.

[80] Bueno B, Norford L, Hidalgo J, Pigeon G. The urban weather generator. Journal of Building Performance Simulation 2013;6(4):269-81.

[81] Bastos J, Batterman SA, Freire F. Significance of mobility in the life-cycle assessment of buildings. Building Research \& Information 2015;1-30.

[82] Anderson JE, Wulfhorst G, Lang W. Energy analysis of the built environment - a review and outlook. Renewable and Sustainable Energy Reviews 2015;44:149-58.

[83] Treloar G, Fay R, Love PED, lyer-Raniga U. Analysing the life-cycle energy of an Australian residential building and its householders. Building Research and Information 2000;28(3):18495. 
[84] Perkins A, Hamnett S, Pullen S, Zito R, Trebilcock D. Transport, housing and urban form: the life cycle energy consumption and emissions of city centre apartments compared with suburban dwellings. Urban Policy and Research 2009;27(4):377-96.

[85] Stephan A, Crawford $\mathrm{RH}$, de Myttenaere K. Towards a more holistic approach to reducing the energy demand of dwellings. Procedia Engineering 2011;21:1033-41.

[86] Stephan A, Crawford RH, de Myttenaere K. Towards a comprehensive life cycle energy analysis framework for residential buildings. Energy and Buildings 2012;55:592-600.

[87] Stephan A, Stephan L. Reducing the total life cycle energy demand of recent residential buildings in Lebanon. Energy 2014;74:618-37.

[88] Reinhart CF, Davila CC. Urban building energy modeling - a review of a nascent field. Building and Environment 2016;97:196-202.

[89] European Comission. Europe 2020: a strategy for smart, sustainable and inclusive growth. 2010. doi:10.1007/s13398-014-0173-7.2.

[90] Torcellini P, Pless S, Deru M, Crawley D. Zero Energy Buildings: a critical look at the definition. ACEEE Summer Study Pacific Grove 2006:15.

[91] Crawley D, Pless S, Torcellini P. Getting to Net Zero Energy Buildings - needs, challenges, opportunities. ASHRAE J 2009.

[92] Marszal AJ, Heiselberg P, Bourrelle JS, Musall E, Voss K, Sartori I, Napolitani A. Zero energy building - a review of definitions and calculation methodologies. Energy and Buildings 2011:43:971-9.

[93] Sartori I, Napolitano A, Voss K. Net zero energy buildings: a consistent definition framework. Energy and Buildings 2012;48:220-32.

[94] Voss K, Sartori I, Lollini R. Nearly-zero, net zero and plus energy buildings. REHVA Journal 2012:23-7.

[95] Garde F, Lenoir A, Scognamiglio A, Aelenei D, Waldren D, Rostvik HN, Ayoub J, Aelenei L, Donn M, Tardif M, Cory S. Design of net zero energy buildings: feedback from international projects. Energy Procedia 2014;61:995-8.

[96] Athienitis A, O'Brien W. Modelling, design and optimization of net-zero energy buildings. Berlin: Ernst \& Sohn; 2015.

[97] International Energy Agency. Transition to sustainable buildings: strategies and opportunities to 2050. 2013. doi:10.1787/9789264202955-en.

[98] United Nations, Department of Economic and Social Affairs, Population Division. World urbanization prospects: the 2014 revision, Highlights (ST/ESA/SER.A/352). 2014.

[99] Ratti C, Baker N, Steemers K. Energy consumption and urban texture. Energy and Buildings 2005;37(7):762-76.

[100] Martos A, Pacheco-Torres R, Ordóñez J, Jadraque-Gago E. Towards successful environmental performance of sustainable cities: Intervening sectors. A review. Renewable and Sustainable Energy Reviews 2016;57:479-95.

[101] Haapio A. Towards sustainable urban communities. Environmental Impact Assessment Review 2012;32(1):165-9.

[102] Sharifi A, Murayama A. A critical review of seven selected neighborhood sustainability assessment tools. Environmental Impact Assessment Review 2013;38:73-87.

[103] Marique A-F, Teller J. Towards sustainable neighbourhoods: a new handbook and its application. in: The Sustainablle City IX 2014;1:177-188.

[104] Ameen RFM, Mourshed M, Li H. A critical review of environmental assessment tools for sustainable urban design. Environmental Impact Assessment Review 2015;55:110-25.

[105] Huang Z, Yu H, Peng Z, Zhao M. Methods and tools for community energy planning: a review. Renewable and Sustainable Energy Reviews 2015;42:1335-48. 
[106] Chastenet CA, Belziti D, Bessis B, Faucheux F, Le Sceller T, Monaco FX, Pech P. The French eco-neighbourhood evaluation model: contributions to sustainable city making and to the evolution of urban practices. Journal of Environmental Management 2016;176:69-78.

[107] Kurnitski J, Saari A, Kalamees T, Vuolle M, Niemelä J, Tark T. Cost optimal and nearly zero (nZEB) energy performance calculations for residential buildings with REHVA definition for nZEB national implementation. Energy and Buildings 2011;43(11):3279-88.

[108] Kurnitski J. REHVA nZEB technical definition and system boundaries for nearly zero energy buildings. Brussels. 2013.

[109] Sanaieian H, Tenpierik M, van den Linden K, Seraj FM, Shemrani SMM. Review of the impact of urban block form on thermal performance, solar access and ventilation. Renewable and Sustainable Energy Reviews 2014;38:551-60.

[110] Gros A, Bozonnet E, Inard C, Musy M. Simulation tools to assess microclimate and building energy - a case study on the design of a new district. Energy and Buildings 2016;114:112-22.

[111] Depecker P, Menezo C, Virgone J, Lepers S. Design of buildings shape and energetic consumption. Building and Environment 2001;36(5):627-35.

[112] Hachem C, Athienitis A, Fazio P. Evaluation of energy supply and demand in solar neighborhood. Energy and Buildings 2012;49:335-47.

[113] Kanters J, Wall M. The impact of urban design decisions on net zero energy solar buildings in Sweden. Urban, Planning and Transport Research 2014;2(1):312-32.

[114] Carlisle N, Geet OV, Pless S. Definition of a 'Zero Net Energy' community - Technical report NREL/TP-7A2-46065. National Renewable Energy Laboratory, 2009.

[115] Baker N, Steemers K. Energy and environment in architecture - a technical design guide. London: E \& FN Spon; 2000.

[116] Compagnon R. Solar and daylight availability in the urban fabric. Energy and Buildings 2004;36(4):321-8.

[117] Hachem C, Fazio P, Athienitis A. Solar optimized residential neighborhoods: evaluation and design methodology. Solar Energy 2013;95:42-64.

[118] Sarralde JJ, Quinn DJ, Wiesmann D, Steemers K. Solar energy and urban morphology: scenarios for increasing the renewable energy potential of neighbourhoods in London. Renewable Energy 2015;73:10-7.

[119] Li D, Liu G, Liao S. Solar potential in urban residential buildings. Solar Energy 2015;111:22535.

[120] Takebayashi H, Ishii E, Moriyama M, Sakaki A, Nakajima S, Ueda H. Study to examine the potential for solar energy utilization based on the relationship between urban morphology and solar radiation gain on building rooftops and wall surfaces. Solar Energy 2015;119:362-9.

[121] Freitas S, Catita C, Redweik P, Brito MC. Modelling solar potential in the urban environment: state-of-the-art review. Renewable and Sustainable Energy Reviews 2015;41:915-31.

[122] Nault E, Peronato G, Rey E, Andersen M. Review and critical analysis of early-design phase evaluation metrics for the solar potential of neighborhood designs. Building and Environment 2015;92:679-91..

[123] Kanters J, Wall M. A planning process map for solar buildings in urban environments. Renewable and Sustainable Energy Reviews 2016;57:173-85.

[124] Mohajeri N, Upadhyay G, Gudmundsson A, Assouline D, Kämpf J, Scartezzini J-L. Effects of urban compactness on solar energy potential. Renewable Energy 2016;93:469-82.

[125] Rezaie B, Rosen MA. District heating and cooling: Review of technology and potential enhancements. Applied Energy 2012;93:2-10.

[126] Allegrini J, Orehounig K, Mavromatidis G, Ruesch F, Dorer V, Evins R. A review of modelling approaches and tools for the simulation of district-scale energy systems. Renewable and Sustainable Energy Reviews 2015;52:1391-404. 
[127] Adil AM, Ko Y. Socio-technical evolution of decentralized energy systems: a critical review and implications for urban planning and policy. Renewable and Sustainable Energy Reviews 2016;57:1025-37.

[128] Talebi B, Mirzaei PA, Bastani A, Haghighat F. A review of district heating systems: modeling and optimization. Frontiers in Built Environment 2016;2:1-14.

[129] Lake A, Rezaie B, Beyerlein S. Review of district heating and cooling systems for a sustainable future. Renewable and Sustainable Energy Reviews 2017;67:417-25.

[130] Kylili A, Fokaides PA. European smart cities: the role of zero energy buildings. Sustainable Cities and Society 2015;15:86-95.

[131] Steemers K. Energy and the city: density, buildings and transport. Energy and Buildings 2003;35(1):3-14.

[132] Koch A, Girad S. Urban neighbourhoods - an intermediate scale for the assessment of energy performance of buildings. in: ECEEE 2011 Summer study - energy efficiency first: the foundation of a low-carbon society, 2011, pp. 1377-85.

[133] Asfour OS, Alshawaf ES. Effect of housing density on energy efficiency of buildings located in hot climates. Energy and Buildings 2015;91:131-8.

[134] Fonseca JA, Schlueter A. Integrated model for characterization of spatiotemporal building energy consumption patterns in neighborhoods and city districts. Applied Energy 2015;142:247-65.

[135] Marique A-F, Reiter S. A simplified framework to assess the feasibility of zero-energy at the neighbourhood/community scale. Energy and Buildings 2014;82:114-22.

[136] International Energy Agency. World energy outlook 2012. OECD Publishing, 2012.

[137] Fischer C. Feedback on household electricity consumption: a tool for saving energy?. Energy Efficiency 2008;1(1):79-104.

[138] Darby S. The effectiveness of feedback on energy consumption. A review for defra of the literature on metering, billing and direct displays. Environmental Change Institute, University of Oxford, 2006.

[139] Soares A, Melo H, Antunes CH, Trovão JP, Gomes Á, Jorge H. Integration of the electric vehicle as a manageable load in a residential energy management system. in: 2015 IEEE Veh. Power Propuls. Conf., Montréal, Canada, 2015.

[140] Soares A, Gomes Á, Antunes CH. Categorization of residential electricity consumption as a basis for the assessment of the impacts of demand response actions. Renewable and Sustainable Energy Reviews 2014;30:490-503.

[141] Gomes A, Martins AG, Figueiredo R. Simulation-based assessment of electric load management programs. International Journal of Energy Research 1999;23(2):169-81.

[142] Deng R, Yang Z, Chow M-Y, Chen J. A Survey on demand response in smart grids: mathematical models and approaches. IEEE Transactions on Industrial Informatics 2015;11(3):570-82.

[143] D'hulst R, Labeeuw W, Beusen B, Claessens S, Deconinck G, Vanthournout K. Demand response flexibility and flexibility potential of residential smart appliances: experiences from large pilot test in Belgium. Applied Energy 2015;155:79-90.

[144] Stamminger PR, Anstett V. Effectiveness of demand side management by variable energy tariffs in the households - results of an experimental design with a fictive tariff model, in: Eceee 2013 Summer Study Proceedings: Rethink, Renew, Restart. pp. 2159-2166; 2013.

[145] Vanthournout K, Dupont B, Foubert W, Stuckens C, Claessens S. An automated residential demand response pilot experiment, based on day-ahead dynamic pricing. Applied Energy 2015;155:195-203.

[146] Soares A, Gomes Á, Antunes CH. Integrated management of energy resources in the residential sector using evolutionary computation: a Review. in: M. del S.G. Cascales, J.M.S. 
Lozano, A.D.M. Arredondo, C.C. Corona (Eds.), Soft Comp. Appl. Renew. Energy Effic., IGI Global, 2015, pp. 320-347.

[147] EC 2010. EU energy trends to 2030 - UPDATE 2009 In: COMMISSION, E. (ed.). Luxembourg, Belgium: Publications Office of the European Union.

[148] Lopes MAR, Antunes CH, Martins N. Towards more effective behavioural energy policy: an integrative modelling approach to residential energy consumption in Europe. Energy Research \& Social Science 2015;7:84-98.

[149] Geelen D, Reinders A, Keyson D. Empowering the end-user in smart grids: recommendations for the design of products and services. Energy Policy 2013;61:151-61.

[150] Van Raaij WF, Verhallen TMM. A behavioral model of residential energy use. Journal of Economic Psychology 1983;3(1):39-63.

[151] Lopes MAR, Antunes CH, Janda KB, Peixoto P, Martins N. The potential of energy behaviours in a smart (er) grid: policy implications from a Portuguese exploratory study. Energy Policy 2016;90:233-45.

[152] Lopes MAR, Antunes CH, Martins N. Energy behaviours as promoters of energy efficiency: a 21st century review. Renewable and Sustainable Energy Reviews 2012;16(6):4095-104.

[153] Lopes MAR, Antunes CH, Reis A, Martins N. Estimating behavioural savings in dwellings using Building Energy Performance Simulations. Building Research and Information 2016 (in press).

[154] Ben H, Steemers K. Energy retrofit and occupant behaviour in protected housing: a case study of the Brunswick Centre in London. Energy and Buildings 2014;80:120-30.

[155] Bonte M, Thellier F, Lartigue B. Impact of occupant's actions on energy building performance and thermal sensation. Energy and Buildings 2014;76:219-27.

[156] Xu P, Xu T, Shen P. Energy and behavioral impacts of integrative retrofits for residential buildings: what is at stake for building energy policy reforms in northern China? Energy Policy 2013;52:667-76.

[157] Al-Mumin A, Khattab O, Sridhar G. Occupants' behavior and activity patterns influencing the energy consumption in the Kuwaiti residences. Energy and Buildings 2003;35(6):549-59.

[158] de Meester T, Marique A-F, de Herde A, Reiter S. Impacts of occupant behaviours on residential heating consumption for detached houses in a temperate climate in the northern part of Europe. Energy and Buildings 2013;57:313-23.

[159] Martinaitis V, Zavadskas EK, Motuziene V, Vilutiene T. Importance of occupancy information when simulating energy demand of energy efficient house: a case study. Energy and Buildings 2015;101:64-75.

[160] EEA 2013. Achieving energy efficiency through behaviour change: what does it take? Copenhagen: European Environment Agency. 2013

[161] Nässén J, Holmberg J. Quantifying the rebound effects of energy efficiency improvements and energy conserving behaviour in Sweden. Energy Efficiency 2009;2(3):221-31.

[162] Ghosh NK, Blackhurst MF. Energy savings and the rebound effect with multiple energy services and efficiency correlation. Ecological Economics 2014;105:55-66.

[163] Schleich J, Mills B, Dütschke E. A brighter future? Quantifying the rebound effect in energy efficient lighting. Energy Policy 2014;72:35-42.

[164] Thomas BA, Azevedo IL. Estimating direct and indirect rebound effects for U.S. households with input - output analysis. Part 2: simulation. Ecological Economics 2013;86:188-98.

[165] Orea L, Llorca M, Filippini M. A new approach to measuring the rebound effect associated to energy efficiency improvements: an application to the US residential energy demand. Energy Economics 2015;49:599-609.

[166] Galvin R. Estimating broad-brush rebound effects for household energy consumption in the EU 28 countries and Norway: some policy implications of Odyssee data. Energy Policy 2014;73:323-32. 
[167] Jantunen M, Oliveira Fernandes E, Carrer P, Kephalopoulos S. Promoting actions for healthy indoor air (IAIAQ). Luxembourg: European Commission Directorate General for Health and Consumers, 2011.

[168] Janda KB. Buildings don't use energy: people do. Architectural Science Review 2011;54(1):1522.

[169] Scientific committee on health and environmental risks. SCHER - Opinion on risk assessment on indoor air quality, 2007.

[170] Kundel S, Kontonasiou E, Arcipowska A, Mariottini F, Atanasiu B. Indoor air quality, thermal comfort and daylight - analysis of residential building regulations in eight EU member states. 2015.

[171] d'Ambrosio Alfano FR, Bellia L, Boerstra A, van Dijken F, Lanniello E, Lopardo G, Minichiello F, Romagnoni P, Gameiro da Silva MC. REHVA - Indoor environment and energy efficiency in schools - Part 1 Principles. REHVA, 2010.

[172] Schneider M. Do school facilities affect academic outcomes?. National clearinghouse for educational facilities, pp. 1-24, 2002.

[173] Wargocki P, Wyon DP. The Effects of outdoor air supply rate and supply air filter condition in classrooms on the performance of schoolwork by children (RP-1257). HVAC\&R Research 2007;13(2):165-91.

[174] Bakó-biró Z, Clements-Croome DJ, Kochhar N, Awbi HB, Williams MJ. Ventilation rates in schools and pupils' performance. Building and Environment 2012;48:215-23.

[175] Corgnati SP, Gameiro da Silva M, Ansaldi R, Asadi E, Costa JJ, Filippi M, Kaczmarczyk J, Melikov AK, Olesen BW, Popiolek Z, Wargocki P. REHVA - Indoor climate quality assessment. REHVA, 2011.

[176] Frontczak M, Wargocki P. Literature survey on how different factors influence human comfort in indoor environments. Building and Environment 2011;46(4):922-37.

[177] Tanabe S-i, Haned M, Nishipana N. Indoor environmental quality and productivity. REHVA Journal, 2007.

[178] Clements-Croome DJ. Influence of social organization and environmental factors and wellbeing in the office workplace. in: Int. Conf. CLIMA 2000 World Congr., 2001.

[179] ASHRAE. ANSI/ASHRAE Standard 55 - Thermal environmental conditions for human occupancy. 2010.

[180] Healy JD. Excess winter mortality in Europe: a cross country analysis identifying key risk factors. Journal of Epidemiology \& Community Health 2003;57:784-9.

[181] CEC, California Energy Commission. Summary of daylighting in schools: reanalysis report. 2003.

[182] Becker R, Goldberger I, Paciuk M. Improving energy performance of school buildings while ensuring indoor air quality ventilation. Building and Environment 2007;42(9):3261-76.

[183] Bernardo H, Dias Pereira L. An integrated approach for energy performance and indoor environmental quality assessment in school buildings. Green Brain of the Year Contest - IPC 2014, 2014.

[184] Howieson S. Are our homes making us ill? The impact of energy efficiency on indoor air quality. Perspectives in Public Health 2014;134(6):318-9.

[185] Howieson S. Housing and asthma. Taylor \& Francis, 2005.

[186] Bakó-biró Z, Kochhar N, Clements-Croome DJ, Awbi HB, Williams M. Ventilation rates in schools and learning performance. in: Proceedings of Clima 2007 WellBeing Indoors, 2007.

[187] EN ISO 7730: 2005. Ergonomics of the thermal environment. Analytical determination and interpretation of thermal comfort using calculation of the PMV and PPD indices and local thermal comfort criteria. 2005. 
[188] de Carvalho PM, Gameiro da Silva M, Ramos JE. Influence of weather and indoor climate on clothing of occupants in naturally ventilated school buildings. Building and Environment 2013;59:38-46.

[189] Havenith G, Holmér I, Parsons K. Personal factors in thermal comfort assessment: clothing properties and metabolic heat production. Energy and Buildings 2002;34(6):581-91.

[190] Heidari S, Sharples S. A comparative analysis of short-term and long-term thermal comfort surveys in Iran. Energy and Buildings 2002;34(6):607-14.

[191] Dias Pereira L, Raimondo D, Corgnati SP, Gameiro da Silva M. Assessment of indoor air quality and thermal comfort in Portuguese secondary classrooms: methodology and results. Building and Environment 2014;81:69-80.

[192] Dias Pereira L, Neto L, Gameiro da Silva M. Indoor air quality and thermal comfort assessment of two Portuguese secondary schools: main results. in: REHVA Annu. Conf. 2015, Riga, Latvia: RTU PRESS, 2015, pp. 49-56.

[193] Dias Pereira L. Modernized Portuguese schools - from IAQ and thermal comfort towards energy efficiency plans. PhD Dissertation in Sustainable Energy Systems, Department of Mechanical Engineering, Faculty of Sciences and Technology of the University of Coimbra. 2016.

[194] CEN. EN 15251:2007 Indoor environmental input parameters for design and assessment of energy performance of buildings addressing indoor air quality, thermal environment, lighting and acoustics, 2007.

[195] Lucarelli MT, Pennestrì D. Gli edifici scolastici e l'indoor air quality: procedure diagnostiche e criteri di intervento. Journal of Technology for Architecture and Environment 2015;9:299-306.

[196] Way M, Bordass B. Making feedback and post-occupancy evaluation routine 2: soft landings involving design and building teams in improving performance. Building Research and Information 2005;33(4):353-60.

[197] Chenari B, Carrilho JD, Gameiro da Silva M. Towards sustainable, energy-efficient and healthy ventilation strategies in buildings: a review. Renewable and Sustainable Energy Reviews 2016;59:1426-47.

[198] Aste N, Manfren M, Marenzi G. Building Automation and Control Systems and performance optimization: A framework for analysis. Renewable and Sustainable Energy Reviews. (in press) DOI: 10.1016/j.rser.2016.10.072.

[199] De Waters J, Powers S. Energy literacy among middle and high school youth. in: $38^{\text {th }}$ ASEE/IEEE Frontiers in Education Conference. Saratoga Springs, NY: 978-1-4244-1970-8/08. Available at: http://www.clarksonuniversity.org/highschool/k12/pdf/FIE08_EnergyLiteracy.pdf.

[200] U.S. Department of Energy (DOE). Energy literacy: essential principles and fundamental concepts for energy education. 2011:1-20.

Available at: https://energy.gov/sites/prod/files/2014/09/f18/Energy_Literacy_Low_Res_3.0.pdf.

[201] Carrilho JD, Chenari B, Gomes MR, Botte G, Mateus M, Gameiro da Silva M. Development of a live laboratory for research and technology demonstration in indoor environment assessment and control. in: Energy for Sustainability 2015 - Sustainable Cities: Designing for People and the Planet, Coimbra, 14-15 May, 2015.

[202] Soares N, Dias Pereira L, Ferreira J, Conceição P, Pereira da Silva P. Energy efficiency of higher education buildings: a case study. International Journal of Sustainability in Higher Education 2015;16(5):669-91.

[203] Kalay YE. Architecture's new media: principles, theories, and methods of computer-aided design. MIT Press, Cambridge, Massachusetts, 2004.

[204] Singh V, Gu N. Towards an integrated generative design framework. Design Studies 2012;33:185-207.

[205] Chakrabarti A, Shea K, Stone RB, Cagan J, Campbell MI, Hernandez NV, Wood KL. Computer-based design synthesis research: an overview. Journal of Computing and Information Science in Engineering 2011;11(2):021003-13. 
[206] António CAC, Monteiro JB, Afonso CF. Optimal topology of urban buildings for maximization of annual solar irradiation availability using a genetic algorithm. Applied Thermal Engineering 2014;73(1):424-37.

[207] Vermeulen T, Knopf-Lenoir C, Villon P, Beckers B. Urban layout optimization framework to maximize direct solar irradiation. Computers, Environment and Urban Systems 2015;51:1-12.

[208] Duarte JP. A discursive grammar for customizing mass housing: the case of Siza's houses at Malagueira. Automation in Construction 2005;14(2):265-75.

[209] Granadeiro V, Duarte JP, Correia JR, Leal VMS. Building envelope shape design in early stages of the design process: integrating architectural design systems and energy simulation. Automation in Construction 2013;32:196-209.

[210] Yi YK, Malkawi AM. Optimizing building form for energy performance based on hierarchical geometry relation. Automation in Construction 2009;18(6):825-33.

[211] Caldas L. Generation of energy-efficient architecture solutions applying GENE_ARCH: an evolution-based generative design system. Advanced Engineering Informatics 2008;22(1):59_ 70.

[212] Wright JA, Brownlee A, Mourshed MM, Wang M. Multi-objective optimization of cellular fenestration by an evolutionary algorithm. Journal of Building Performance Simulation 2014;7(1):33-51.

[213] Virirakis L. GENETICA: a computer language that supports general formal expression with evolving data structures. IEEE Transactions on Evolutionary Computation 2003;7(5):456-81.

[214] Rodrigues E, Gaspar AR, Gomes Á. An approach to the multi-level space allocation problem in architecture using a hybrid evolutionary technique. Automation in Construction 2013;35:48298.

[215] Shea K, Aish R, Gourtovaia M. Towards integrated performance-driven generative design tools. Automation in Construction 2005;14(2):253-64.

[216] Wonka P, Wimmer M, Sillion F, Ribarsky W. Instant Architecture. ACM Transactions on Graphics (TOG) - Proceedings of ACM SIGGRAPH 2003;22(3):669-77.

[217] Baykan CA, Fox MS. Spatial synthesis by disjunctive constraint satisfaction. Artificial Intelligence for Engineering Design, Analysis and Manufacturing 1997;11(4):245-62.

[218] Merrell P, Schkufza E, Li Z, Agrawala M, Koltun V. Interactive furniture layout using interior design guidelines. ACM Trans. Graph. 2011;30(4):1-10.

[219] Kalay YE. Performance-based design. Automation in Construction 1999;8:395-409.

[220] Whyte J. Towards a new craft of architecture. Building Research \& Information 2015;43(2):263-5.

[221] Oxman R. Performance-based design: current practices and research issues. International Journal of Architectural Computing 2008;6:1-17.

[222] Rodrigues E, Gaspar AR, Gomes Á. Improving thermal performance of automatically generated floor plans using a geometric variable sequential optimization procedure. Applied Energy 2014;132:200-15.

[223] Evins R. A review of computational optimisation methods applied to sustainable building design. Renewable and Sustainable Energy Reviews 2013;22:230-45.

[224] Machairas V, Tsangrassoulis A, Axarli K. Algorithms for optimization of building design: a review. Renewable and Sustainable Energy Reviews 2014;31:101-12.

[225] Rodrigues E, Gaspar AR, Gomes Á. Automated approach for design generation and thermal assessment of alternative floor plans. Energy and Buildings 2014;81:170-81.

[226] Mitchell WJ. Techniques of automated design in architecture: a survey and evaluation. Computers \& Urban Society 1975;1(1):49-76.

[227] Renner G, Ekárt A. Genetic algorithms in computer aided design. Computer-Aided Design 2003;35(8):709-26. 
[228] Attia S, Gratia E, Herde AD, Hensen JLM. Simulation-based decision support tool for early stages of zero-energy building design. Energy and Buildings 2012;49:2-15.

[229] Magnier L, Haghighat F. Multiobjective optimization of building design using TRNSYS simulations, genetic algorithm, and Artificial Neural Network. Building and Environment 2010;45(3):739-46.

[230] Melo AP, Cóstola D, Lamberts R, Hensen JLM. Development of surrogate models using artificial neural network for building shell energy labelling. Energy Policy 2014;69:457-66.

[231] Granadeiro V, Correia JR, Leal VMS, Duarte JP. Envelope-related energy demand: a design indicator of energy performance for residential buildings in early design stages. Energy and Buildings 2013;61:215-23.

[232] Rodrigues E, Amaral AR, Gaspar AR, Gomes Á. How reliable are geometry-based building indices as thermal performance indicators?. Energy Conversion and Management 2015;101:561-78.

[233] Kaklauskas A, Zavadskas EK, Raslanas S. Multivariant design and multiple criteria analysis of building refurbishments. Energy and Buildings 2005;37:361-72.

[234] Gero JS, D'cruz N, Radford A. Energy in context - a multicriteria model for building design. Building and Environment 1983;18(3):99-107.

[235] Jaggs M, Palmer J. Energy performance indoor environmental quality retrofit - a European diagnosis and decision making method for building refurbishment. Energy and Buildings 2000;31(2):97-101.

[236] Flourentzou F, Roulet C-A. Elaboration of retrofit scenarios. Energy and Buildings 2002;34(2):185-92.

[237] Rey E. Office building retrofitting strategies: multicriteria approach of an architectural and technical issue. Energy and Buildings 2004;36(4):367-72.

[238] Asadi E, Gameiro da Silva M, Antunes CH, Dias L. A multi-objective optimization model for building retrofit strategies using TRNSYS simulations, GenOpt and MATLAB. Building and Environment 2012;56:370-8.

[239] Diakaki C, Grigoroudis E, Kolokotsa D. Towards a multi-objective optimization approach for improving energy efficiency in buildings. Energy and Buildings 2008;40(9):1747-54.

[240] Asadi E, Gameiro da Silva M, Antunes CH, Dias L. Multi-objective optimization for building retrofit strategies: a model and an application. Energy and Buildings 2012;44:81-7.

[241] Diakaki C, Grigoroudis E, Kabelis N, Kolokotsa D, Kalaitzakis K, Stavrakakis G. A multiobjective decision model for the improvement of energy efficiency in buildings. Energy 2010;35(12):5483-96.

[242] Asadi E, Antunes CH, Gameiro da Silva M, Dias LC. State-of-the-art on retrofit strategies selection using multi-objective optimization and genetic algorithms - a multidisciplinary approach. In: Torgal F, Mistretta M, Kaklauskas A, Granqvist CG, editors. Nearly Zero Energy Building Refurbishment. UK: Springer London, 2013, pp. 279-297.

[243] Juan Y-K, Kim JH, Roper K, Castro-Lacouture D. GA-based decision support system for housing condition assessment and refurbishment strategies. Automation in Construction 2009;18(4):394-401.

[244] Wright JA, Loosemore HA, Farmani R. Optimization of building thermal design and control by multi-criterion genetic algorithm. Energy and Buildings 2002;34(2):959-72.

[245] Hamdy M, Hasan A, Siren K. Applying a multi-objective optimization approach for design of low-emission cost-effective dwellings. Building and Environment 2011;46(1):109-23.

[246] Peippo K, Lund PD, Vartiainen E. Multivariate optimization of design trade-offs for solar low energy buildings. Energy and Buildings 1999;29(2):189-205.

[247] Caldas LG, Norford LK. A design optimization tool based on a genetic algorithm. Automation in Construction 2011;11(2):173-84. 
[248] Wang W, Zmeureanu R, Rivard H. Applying multi-objective genetic algorithms in green building design optimization. Building and Environment 2005;40(11):1512-25.

[249] Jin Y. A comprehensive survey of fitness approximation in evolutionary computation. Soft Computing 2005;9(1):3-12.

[250] Soares N. Thermal energy storage with Phase Change Materials (PCMs) for the improvement of the energy performance of buildings. PhD Dissertation in Sustainable Energy Systems, Department of Mechanical Engineering, Faculty of Sciences and Technology of the University of Coimbra. 2015.

[251] Soares N, Costa JJ, Gaspar AR, Santos P. Review of passive PCM latent heat thermal energy storage systems towards buildings' energy efficiency. Energy and Buildings 2013;59:82-103.

[252] Yuan Y, Zhang N, Tao W, Cao X, He Y. Fatty acids as phase change materials: a review. Renewable and Sustainable Energy Reviews 2014;29:482-98.

[253] Pielichowska K, Pielichowski K. Phase change materials for thermal energy storage. Progress in Materials Science 2014;65:67-123.

[254] Ge H, Li H, Mei S, Liu J. Low melting point liquid metal as a new class of phase change material: an emerging frontier in energy area. Renewable and Sustainable Energy Reviews 2013;21:331-46.

[255] Zalba B, Marín JM, Cabeza LF, Mehling H. Review on thermal energy storage with phase change: materials, heat transfer analysis and applications. Applied Thermal Engineering 2003;23(3):251-83.

[256] Sharma A, Tyagi VV, Chen CR, Buddhi D. Review on thermal energy storage with phase change materials and applications. Renewable and Sustainable Energy Reviews 2009;13(2):318-45.

[257] Farid MM, Khudhair AM, Razack SAK, Al-Hallaj S. A review on phase change energy storage: materials and applications. Energy Conversion and Management 2004;45(9-10):1597-615.

[258] Rao Z, Wang S, Zhang Z. Energy saving latent heat storage and environmental friendly humidity-controlled materials for indoor climate. Renewable and Sustainable Energy Reviews 2012;16(5):3136-45.

[259] Cabeza LF, Castell A, Barreneche C, de Gracia A, Fernández Al. Materials used as PCM in thermal energy storage in buildings: a review. Renewable and Sustainable Energy Reviews 2011;15(3):1675-95.

[260] Sharma SD, Sagara K. Latent heat storage materials and systems: a review. International Journal of Green Energy 2005:2:1-56.

[261] Sharma RK, Ganesan P, Tyagi VV, Metselaar HSC, Sandaran SC. Developments in organic solid-liquid phase change materials and their applications in thermal energy storage. Energy Conversion and Management 2015;95:193-228.

[262] Riffat S, Mempouo B, Fang W. Phase change material developments: a review. International Journal of Ambient Energy 2015;36(3):102-15.

[263] Tatsidjodoung $P$, Le Pierrès N, Luo L. A review of potential materials for thermal energy storage in building applications. Renewable and Sustainable Energy Reviews 2013;18:327-49.

[264] Memon SA. Phase change materials integrated in building walls: a state of the art review. Renewable and Sustainable Energy Reviews 2014;31:870-906.

[265] Su W, Darkwa J, Kokogiannakis G. Review of solid-liquid phase change materials and their encapsulation technologies. Renewable and Sustainable Energy Reviews 2015;48:373-91.

[266] Kousksou T, Bruel P, Jamil A, El Rhafiki T, Zeraouli Y. Energy storage: applications and challenges. Solar Energy Materials and Solar Cells 2014;120:59-80.

[267] Tyagi VV, Buddhi D. PCM thermal storage in buildings: a state of art. Renewable and Sustainable Energy Reviews 2007;11(6):1146-66.

[268] Kenisarin M, Mahkamov K. Solar energy storage using phase change materials. Renewable and Sustainable Energy Reviews 2007;11(9):1913-65. 
[269] Cabeza LF, Barreneche C, Martorell I, Miró L, Sari-Bey S, Fois M, Paksoy HO, Sahan N, Weber R, Constantinescu M, Anghel EM, Malikova M, Krupa I, Delgado M, Dolado P, Furmanski P, Jaworski M, Haussmann T, Gschwander S, Fernández Al. Unconventional experimental technologies available for phase change materials (PCM) characterization. Part 1. Thermophysical properties. Renewable and Sustainable Energy Reviews 2015;43:1399414.

[270] Kuznik F, David D, Johannes K, Roux J-J. A review on phase change materials integrated in building walls. Renewable and Sustainable Energy Reviews 2011;15(1):379-91.

[271] Zhou D, Zhao CY, Tian Y. Review on thermal energy storage with phase change materials (PCMs) in building applications. Applied Energy 2012;92:593-605.

[272] Cheng R, Wang X, Zhang Y. Energy-efficient building envelopes with phase-change materials: new understanding and related research. Heat Transfer Engineering 2014;35(11-12):970-84.

[273] Soares N, Gaspar AR, Santos P, Costa JJ. Experimental study of the heat transfer through a vertical stack of rectangular cavities filled with phase change materials. Applied Energy 2015;142:192-205.

[274] Rathod MK, Banerjee J. Thermal stability of phase change materials used in latent heat energy storage systems: a review. Renewable and Sustainable Energy Reviews 2013;18:246-58.

[275] Soares N, Gaspar AR, Santos P, Costa JJ. Experimental evaluation of the heat transfer through small PCM-based thermal energy storage units for building applications. Energy and Buildings 2016;116:18-34.

[276] Agyenim F, Hewitt N, Eames P, Smyth M. A review of materials, heat transfer and phase change problem formulation for latent heat thermal energy storage systems (LHTESS). Renewable and Sustainable Energy Reviews 2010;14(2):615-28.

[277] Waqas A, Din ZU. Phase change material (PCM) storage for free cooling of buildings - a review. Renewable and Sustainable Energy Reviews 2013;18:607-25.

[278] Regin AF, Solanki SC, Saini JS. Heat transfer characteristics of thermal energy storage system using PCM capsules: a review. Renewable and Sustainable Energy Reviews 2008;12(9):243858.

[279] Zhang Y, Zhou G, Lin K, Zhang Q, Di H. Application of latent heat thermal energy storage in buildings: state-of-the-art and outlook. Building and Environment 2007;42(6):2197-209.

[280] Salunkhe PB, Shembekar PS. A review on effect of phase change material encapsulation on the thermal performance of a system. Renewable and Sustainable Energy Reviews 2012;16(8):5603-16.

[281] Whiffen TR, Riffat SB. A review of PCM technology for thermal energy storage in the built environment: part I. International Journal of Low-Carbon Technologies 2012;1-12.

[282] Tyagi VV, Kaushik SC, Tyagi SK, Akiyama T. Development of phase change materials based microencapsulated technology for buildings: a review. Renewable and Sustainable Energy Reviews 2011;15(2):1373-91.

[283] Zhao CY, Zhang GH. Review on microencapsulated phase change materials (MEPCMs): fabrication, characterization and applications. Renewable and Sustainable Energy Reviews 2011;15(8):3813-32.

[284] Chen Z, Fang G. Preparation and heat transfer characteristics of microencapsulated phase change material slurry: a review. Renewable and Sustainable Energy Reviews 2011;15(9):4624-32.

[285] Jamekhorshid A, Sadrameli SM, Farid M. A review of microencapsulation methods of phase change materials (PCMs) as a thermal energy storage (TES) medium. Renewable and Sustainable Energy Reviews 2014;31:531-42.

[286] Cao L, Su D, Tang Y, Fang G, Tang F. Properties evaluation and applications of thermal energy storage materials in buildings. Renewable and Sustainable Energy Reviews 2015;48:500-22. 
[287] Delgado M, Lázaro A, Mazo J, Zalba B. Review on phase change material emulsions and microencapsulated phase change material slurries: materials, heat transfer studies and applications. Renewable and Sustainable Energy Reviews 2012;16(1):253-73.

[288] Youssef Z, Delahaye A, Huang L, Trinquet F, Fournaison L, Pollerberg C, Doetsch C. State of the art on phase change material slurries. Energy Conversion and Management 2013;65:12032.

[289] Fang G, Tang F, Cao L. Preparation, thermal properties and applications of shape-stabilized thermal energy storage materials. Renewable and Sustainable Energy Reviews 2014;40:23759.

[290] Yang C, Fischer L, Maranda S, Worlitschek J. Rigid polyurethane foams incorporated with phase change materials: a state-of-the-art review and future research pathways. Energy and Buildings 2015;87:25-36.

[291] Pomianowski M, Heiselberg P, Zhang Y. Review of thermal energy storage technologies based on PCM application in buildings. Energy and Buildings 2013;67:56-69.

[292] Jegadheeswaran S, Pohekar SD. Performance enhancement in latent heat thermal storage system: a review. Renewable and Sustainable Energy Reviews 2009;13(9):2225-44.

[293] Fan L, Khodadadi JM. Thermal conductivity enhancement of phase change materials for thermal energy storage: a review. Renewable and Sustainable Energy Reviews 2011;15(1):2446.

[294] Liu S, Li Y, Zhang Y. Review on heat transfer mechanisms and characteristics in encapsulated PCMs. Heat Transfer Engineering 2015;36(10):880-901.

[295] AL-Saadi SN, Zhai Z(J). Modeling phase change materials embedded in building enclosure: a review. Renewable and Sustainable Energy Reviews 2013;21:659-73.

[296] Al-Abidi AA, Mat SB, Sopian K, Sulaiman MY, Mohammed AT. CFD applications for latent heat thermal energy storage: a review. Renewable and Sustainable Energy Reviews 2013;20:35363.

[297] Verma P, Varun SK, Singal. Review of mathematical modeling on latent heat thermal energy storage systems using phase-change material. Renewable and Sustainable Energy Reviews 2008;12(4):999-1031.

[298] Dutil Y, Rousse DR, Salah NB, Lassue S, Zalewski L. A review on phase-change materials: mathematical modeling and simulations. Renewable and Sustainable Energy Reviews 2011;15(1):112-30.

[299] Dutil Y, Rousse D, Lassue S, Zalewski L, Joulin A, Virgone J, Kuznik F, Johannes K, Dumas J$P$, Bédécarrats J-P, Castell A, Cabeza LF. Modeling phase change materials behavior in building applications: Comments on material characterization and model validation. Renewable Energy 2014;61:132-5.

[300] Baetens R, Jelle BP, Gustavsen A. Phase change materials for building applications: a stateof-the-art review. Energy and Buildings 2010;42(9):1361-8.

[301] Pasupathy A, Velraj R, Seeniraj RV. Phase change material-based building architecture for thermal management in residential and commercial establishments. Renewable and Sustainable Energy Reviews 2008;12(1):39-64.

[302] Khudhair AM, Farid MM. A review on energy conservation in building applications with thermal storage by latent heat using phase change materials. Energy Conversion and Management 2004;45(2):263-75.

[303] Zhu N, Ma Z, Wang S. Dynamic characteristics and energy performance of buildings using phase change materials: a review. Energy Conversion and Management 2009;50(12):3169-81.

[304] Parameshwaran R, Kalaiselvam S, Harikrishnan S, Elayaperumal A. Sustainable thermal energy storage technologies for buildings: a review. Renewable and Sustainable Energy Reviews 2012;16(5):2394-433.

[305] Whiffen TR, Riffat SB. A review of PCM technology for thermal energy storage in the built environment: part II. International Journal of Low-Carbon Technologies 2013;8(3):159-64. 
[306] Jeon J, Lee J-H, Seo J, Jeong S-G, Kim S. Application of PCM thermal energy storage system to reduce building energy consumption. Journal of Thermal Analysis and Calorimetry 2013;111:279-88.

[307] Kalnaes SE, Jelle BP. Phase change materials and products for building applications: a stateof-the-art review and future research opportunities. Energy and Buildings 2015;94:150-76.

[308] Basecq V, Michaux G, Inard C, Blondeau P. Short-term storage systems of thermal energy for buildings: a review. Advances in Building Energy Research 2013;7(1):66-119.

[309] Soares N, Costa JJ, Samagaio A, Vicente R. Numerical evaluation of a phase change materialshutter using solar energy for winter nighttime indoor heating. Journal of Building Physics 2014;37(4):367-94.

[310] Soares N, Samagaio A, Vicente R, Costa J. Numerical simulation of a PCM shutter for buildings space heating during the winter. in: Proceedings of WREC - World Renewable Energy Congress 2011, Linköping, Sweden, 8-13 May, 2011.

[311] Silva T, Vicente R, Soares N, Ferreira V. Experimental testing and numerical modelling of masonry wall solution with PCM incorporation: a passive construction solution. Energy and Buildings 2012;49:235-45.

[312] Soares N, Gaspar AR, Santos P, Costa JJ. Multi-dimensional optimization of the incorporation of PCM-drywalls in lightweight steel-framed residential buildings in different climates. Energy and Buildings 2014;70:411-21.

[313] Saffari M, de Gracia A, Ushak S, Cabeza LF. Economic impact of integrating PCM as passive system in buildings using Fanger comfort model. Energy and Buildings 2016;112:159-72.

[314] Soares N, Reinhart CF, Hajiah A. Simulation-based analysis of the use of PCM-wallboards to reduce cooling energy demand and peak-loads in low-rise residential heavyweight buildings in Kuwait. Building Simulation (in press). doi:10.1007/s12273-017-0347-2.

[315] Raj VAA, Velraj R. Review on free cooling of buildings using phase change materials. Renewable and Sustainable Energy Reviews 2010;14(9):2819-29.

[316] Osterman E, Tyagi VV, Butala V, Rahim NA, Stritih U. Review of PCM based cooling technologies for buildings. Energy and Buildings 2012;49:37-49.

[317] Kamali S. Review of free cooling system using phase change material for building. Energy and Buildings 2014;80:131-6.

[318] Al-Abidi AA, Mat SB, Sopian K, Sulaiman MY, Lim CH, Th A. Review of thermal energy storage for air conditioning systems. Renewable and Sustainable Energy Reviews 2012;16(8):580219.

[319] Zhai XQ, Wang XL, Wang T, Wang RZ. A review on phase change cold storage in airconditioning system: materials and applications. Renewable and Sustainable Energy Reviews 2013;22:108-20.

[320] Rodriguez-Ubinas E, Ruiz-Valero L, Vega S, Neila J. Applications of phase change material in highly energy-efficient houses. Energy and Buildings 2012;50:49-62.

[321] Nkwetta DN, Haghighat F. Thermal energy storage with phase change material - a state-of-the art review. Sustainable Cities and Society 2014;10:87-100.

[322] Sharif MKA, Al-Abidi AA, Mat S, Sopian K, Ruslan MH, Sulaiman MY, Rosli MAM. Review of the application of phase change material for heating and domestic hot water systems. Renewable and Sustainable Energy Reviews 2015;42:557-68.

[323] Alkilani MM, Sopian K, Alghoul MA, Sohif M, Ruslan MH. Review of solar air collectors with thermal storage units. Renewable and Sustainable Energy Reviews 2011;15(3):1476-90.

[324] Tian Y, Zhao CY. A review of solar collectors and thermal energy storage in solar thermal applications. Applied Energy 2013;104:538-53.

[325] Chidambaram LA, Ramana AS, Kamaraj G, Velraj R. Review of solar cooling methods and thermal storage options. Renewable and Sustainable Energy Reviews 2011;15(6):3220-8. 
[326] Pintaldi S, Perfumo C, Sethuvenkatraman S, White S, Rosengarten G. A review of thermal energy storage technologies and control approaches for solar cooling. Renewable and Sustainable Energy Reviews 2015;41:975-95.

[327] Chandrasekar M, Rajkumar S, Valavan D. A review on the thermal regulation techniques for non integrated flat PV modules mounted on building top. Energy and Buildings 2015;86:692-7.

[328] Ma T, Yang H, Zhang Y, Lu L, Wang X. Using phase change materials in photovoltaic systems for thermal regulation and electrical efficiency improvement: a review and outlook. Renewable and Sustainable Energy Reviews 2015;43:1273-84.

[329] Du D, Darkwa J, Kokogiannakis G. Thermal management systems for Photovoltaics (PV) installations: a critical review. Solar Energy 2013;97:238-54.

[330] Ling Z, Zhang Z, Shi G, Fang X, Wang L, Gao X, Fang Y, Xu T, Wang S, Liu X. Review on thermal management systems using phase change materials for electronic components, Li-ion batteries and photovoltaic modules. Renewable and Sustainable Energy Reviews 2014;31:427-38.

[331] Hasan A, McCormack SJ, Huang MJ, Norton B. Evaluation of phase change materials for thermal regulation enhancement of building integrated photovoltaics. Solar Energy 2010;84(9):1601-12.

[332] Browne MC, Norton B, McCormack SJ. Phase change materials for photovoltaic thermal management. Renewable and Sustainable Energy Reviews 2015;47:762-82.

[333] Makki A, Omer S, Sabir H. Advancements in hybrid photovoltaic systems for enhanced solar cells performance. Renewable and Sustainable Energy Reviews 2015;41:658-84.

[334] Jegadheeswaran S, Pohekar SD, Kousksou T. Exergy based performance evaluation of latent heat thermal storage system: a review. Renewable and Sustainable Energy Reviews 2010;14(9):2580-95.

[335] Oró E, de Gracia A, Castell A, Farid MM, Cabeza LF. Review on phase change materials (PCMs) for cold thermal energy storage applications. Applied Energy 2012;99:513-33.

[336] Fernandes D, Pitié F, Cáceres G, Baeyens J. Thermal energy storage: "How previous findings determine current research priorities". Energy 2012;39(1):246-57.

[337] Mondal S. Phase change materials for smart textiles - an overview. Applied Thermal Engineering 2008;28(11-12):1536-50.

[338] Calm JM. The next generation of refrigerants - historical review, considerations, and outlook. International Journal of Refrigeration 2008;31(7):1123-33.

[339] Sarbu I. A review on substitution strategy of non-ecological refrigerants from vapour compression-based refrigeration, air-conditioning and heat pump systems. International Journal of Refrigeration 2014;46:123-41.

[340] Mohanraj M, Jayaraj S, Muraleedharan C. Environment friendly alternatives to halogenated refrigerants - a review. International Journal of Greenhouse Gas Control 2009;3(1):108-19.

[341] Wang CC. System performance of R-1234yf refrigerant in air-conditioning and heat pump system - an overview of current status. Applied Thermal Engineering 2014;73(2);1412-20.

[342] Pitarch M, Navarro-Peris E, Gonzálvez J, Corberan J. Analysis and optimization of different two-stage transcritical carbon dioxide cycles for heating applications. International Journal of Refrigeration 2016;(70):235-42.

[343] Mota-Babiloni A, Navarro-Esbrí J, Molés F, Cervera ÁB, Peris B, Verdú G. A review of refrigerant R1234ze(E) recent investigations. Applied Thermal Engineering 2016;95:211-22.

[344] Pitarch M, Navarro-Peris E, Gonzálvez-Maciá J, Corberán JM. Evaluation of different heat pump systems for sanitary hot water production using natural refrigerants. Applied Energy 2017;(190): 911-9.

[345] Kilicarslan A, Müller N. A comparative study of water as a refrigerant with some current refrigerants. International Journal of Energy Research 2005;29(11):947-59. 
[346] ASHRAE, 2008 ASHRAE Handbook HVAC Systems and Equipment I. American Society of Heating Refrigerating and Air-Conditioning Engineers, ed., Atlanta. 2008.

[347] Godson L, Raja B, Lal DM, Wongwises S. Enhancement of heat transfer using nanofluids - an overview. Renewable and Sustainable Energy Reviews 2010;14(2):629-41.

[348] Tarodiya R, Gandhi BK. Hydraulic performance and erosive wear of centrifugal slurry pumps a review. Powder Technology 2017;305:27-38.

[349] Wen D, Lin G, Vafaei S, Zhang K. Review of nanofluids for heat transfer applications. Particuology 2009;7(2):141-50.

[350] Kakaç S, Pramuanjaroenkij A. Review of convective heat transfer enhancement with nanofluids. International Journal of Heat and Mass Transfer 2009;52(13-14):3187-96.

[351] Kulkarni DP, Das DK, Vajjha RS. Application of nanofluids in heating buildings and reducing pollution. Applied Energy 2009;86(12);2566-73.

[352] Esfe MH, Saedodin S, Yan W-M, Afrand M, Sina N. Study on thermal conductivity of waterbased nanofluids with hybrid suspensions of $\mathrm{CNTs} / \mathrm{Al}_{2} \mathrm{O}_{3}$ nanoparticles. Journal of Thermal Analysis and Calorimetry 2016;124(1):455-60.

[353] Hung Y-H, Teng T-P, Teng T-C, Chen J-H. Assessment of heat dissipation performance for nanofluid. Applied Thermal Engineering 2012;32:132-40.

[354] Hatami M, Domairry G, Mirzababaei SN. Experimental investigation of preparing and using the $\mathrm{H}_{2} \mathrm{O}$ based nanofluids in the heating process of HVAC system model. International Journal of Hydrogen Energy (in press).

[355] Cárdenas Gómez AO, Hoffmann ARK, Bandarra Filho EP. Experimental evaluation of CNT nanofluids in single-phase flow. International Journal of Heat and Mass Transfer 2015;86:27787.

[356] Firouzfar E, Soltanieh M, Noie SH, Saidi SH. Energy saving in HVAC systems using nanofluid. Applied Thermal Engineering 2011;31(8-9):1543-5.

[357] Hu X, Zhang Y. Novel insight and numerical analysis of convective heat transfer enhancement with microencapsulated phase change material slurries: laminar flow in a circular tube with constant heat flux. International Journal of Heat and Mass Transfer 2002;45(15):3163-72.

[358] Zeng R, Wang X, Chen B, Zhang Y, Niu J, Wang X, Di H. Heat transfer characteristics of microencapsulated phase change material slurry in laminar flow under constant heat flux. Applied Energy 2009;86(12):2661-70.

[359] Wang F, Maidment G, Missenden J, and Tozer R. The novel use of phase change materials in refrigeration plant. Part 2: dynamic simulation model for the combined system. Applied Thermal Engineering 2007;27(17-18):2902-10.

[360] Shao J, Darkwa J, Kokogiannakis G. Review of phase change emulsions (PCMEs) and their applications in HVAC systems. Energy and Buildings 2015;94:200-17.

[361] Shao J, Darkwa J, Kokogiannakis G. Development of a novel phase change material emulsion for cooling systems. Renewable Energy 2016;87:509-16.

[362] Jurkowska M, Szczygieł I. Review on properties of microencapsulated phase change materials slurries (mPCMS). Applied Thermal Engineering 2016;98:365-73.

[363] Chen B, Wang X, Zeng R, Zhang Y, Wang X, Niu J, Li Y, Di H. An experimental study of convective heat transfer with microencapsulated phase change material suspension: laminar flow in a circular tube under constant heat flux. Experimental Thermal and Fluid Science 2008;32(8):1638-46.

[364] Heier J, Bales C, Martin V. Combining thermal energy storage with buildings - a review. Renewable and Sustainable Energy Reviews 2015;42:1305-25.

[365] Kumaresan V, Chandrasekaran P, Nanda M, Maini AK, Velraj R. Role of PCM based nanofluids for energy efficient cool thermal storage system. International Journal of Refrigeration 2013;36(6):1641-47. 
[366] Mehling H, Cabeza LF. Heat and cold storage with PCM: an up to date introduction into basics and applications. Springer 2008.

[367] ASHRAE, 2013 ASHRAE Handbook - Fundamentals 2013 I. American Society of Heating Refrigerating and Air- Conditioning Engineers, ed., Atlanta. 2013.

[368] Pérez-lombard L, Ortiz J, Coronel JF, Maestre IR. A review of HVAC systems requirements in building energy regulations. Energy and Buildings 2011;43(2-3):255-68.

[369] Ma Z, Wang S. An optimal control strategy for complex building central chilled water systems for practical and real-time applications. Building and Environment 2009;44(6):1188-98.

[370] Sun Y, Huang G. Recent Developments in HVAC System Control and Building Demand Management. Current Sustainable/Renewable Energy Reports (in press). doi:10.1007/s40518017-0064-6

[371] Asad HS, Yuen RKK, Huang G. Multiplexed real-time optimization of HVAC systems with enhanced control stability. Applied Energy 2017;187:640-51. 